\title{
Heritability, Correlation, and Genotype by Environment Interaction of Phenological and Fruit Quality Traits in Peach
}

\author{
Zena Rawandoozi, Timothy Hartmann, and David Byrne \\ Department of Horticultural Sciences, Texas A\&M University, 495 Horticulture Road, College \\ Station, TX 77843 \\ Silvia Carpenedo \\ Embrapa Temperate Agriculture, The Brazilian Agricultural Research Corporation/Rodovia BR 392, \\ $\mathrm{km}$ 78, $9^{\circ}$ Distrito, RS, 96010-971, Pelotas, Brazil
}

\begin{abstract}
AdDitional INDEX wORDs. blush, nectarine, pantao, pleiotropic effects, Prunus persica, soluble solids concentration
Abstract. Ten phenological and fruit quality traits were evaluated in seedlings from nine $F_{1}$ low to medium chill fullsib peach (Prunus persica) families and their parents over 2 years at two locations (Fowler, CA, and College Station, TX) to estimate variance components, genotype by environment interaction $(\mathrm{G} \times \mathbf{E})$, and phenotypic correlations using restricted maximum likelihood mixed and multivariate models. The removal of nectarine $[P$. persica var. nucipersica (fruit without fuzz)] and pantao (flat shape fruit) seedlings from the analysis decreased the heritability for the fruit size, blush, tip, and soluble solids concentration (SSC), indicating the importance of taking the effects of the major gene of nectarine/pantao into account when assessing the heritability of traits. A strong correlation coefficient $(r=$ 0.92) found between ripe date (RD) and fruit development period (FDP) and between fruit weight (FW) and fruit diameter (FD), indicates that either measure is equally effective, although the negative correlation between bloom date (BD) and FDP $(r=-0.46)$ implies earlier blooming during cool temperatures tends to extend FDP. FW, FD, blush, and SSC had moderately weak correlations with $\mathrm{RD}(\mathrm{r}=0.56,0.53,-0.41$, and 0.48$)$ and $\mathrm{FDP}(\mathrm{r}=0.57,0.56$, -0.50 , and 0.39 , respectively), which could be explained either by the presence of a strong link between quantitative trait loci of these traits and the ripening date locus or the pleiotropic effect of ripening date on many quantitative fruit characters. The traits RD, FDP, and titratable acidity (TA) had the highest broad-sense heritability $\left(\mathrm{H}^{2}\right)$ and lowest $\mathbf{G} \times \mathbf{E}$. FW, tip, and shape showed the lowest $\mathbf{H}^{2}$, the highest of $\mathbf{G} \times \mathbf{E}$ variance to the genetic $\mathbf{F}$ (G) $\times \mathbf{E}$ variance/total genotypic variance), and high $\mathbf{G} \times \mathbf{E}$, whereas the other traits showed moderate $\mathbf{G} \times \mathbf{E}$. For the traits that had a higher $\mathbf{G} \times \mathbf{E}$ interaction, selection for or against these traits should be done at the production location. A moderate narrowsense heritability $\left(h^{2}\right)$ was estimated for BD, blush, fruit tip, and shape. FW and FD showed low to moderate $h^{2}$ while $\mathrm{H}^{2}$ was high, whereas RD, FDP, SSC, and TA showed low $\mathrm{h}^{2}$ and high $\mathrm{H}^{2}$ estimates, indicating important nonadditive effects for these traits.
\end{abstract}

Peach (Prunus persica) is among the five most-produced tree fruit crops in the United States $(\approx 875,000 \mathrm{t})$ and the world $(\approx 24.5$ million tonnes) (Food and Agriculture Organization of the United Nations, 2020). The fruit skin can be either pubescent (peach) or glabrous [nectarine (P. persica var. nucipersica)]. Nectarine is controlled by a recessive gene $(g)$ and mapped on linkage group 5 (LG5) (Dirlewanger et al., 1998). Also, the peach fruit shape differs from round to flat (pantao) in appearance (Bassi and Monet, 2008; Blake, 1932). It is controlled by the $S$-locus (Lesley, 1940) located at the end of LG6 (Dirlewanger et al., 1998). The fruit is characterized by varying the flesh color from white, yellow, orange, and red, and these color variations are a result of different levels of carotenoid and anthocyanin compounds (Cevallos-Casals et al., 2006).

Received for publication 24 Aug. 2020. Accepted for publication 27 Oct. 2020. Published online 3 December 2020

This work was supported by the U.S. Department of Agriculture, National Institute of Food and Agriculture Specialty Crop Research Initiative projects, Crop Research Initiative projects, "RosBREED: Enabling marker-assisted breeding in Rosaceae" (2009-51181-05808).

Z.R. is the corresponding author. E-mail: zjmansur@tamu.edu.

This is an open access article distributed under the CC BY-NC-ND license (https://creativecommons.org/licenses/by-nc-nd/4.0/).
In recent years, anthocyanin-rich fruits and vegetables have become more attractive to consumers and making them more marketable compared with other crops as they have healthpromoting properties. Research at Texas A\&M University (TAMU) has highlighted the importance of antioxidant activity of stone fruit (Prunus sp.) and that some of them overlapped that of rabbiteye blueberry [Vaccinium ashei (Vizzotto et al., 2007)].

Recent trends in peach breeding include developing cultivars that extend the harvest period and are adapted to subtropical and tropical zones. This is a response to consumer demands to have peach fruit available throughout the year (Byrne, 2012). Likewise, fruit quality is essential for a new commercial cultivar. Selection for these traits is complicated because most of them are controlled by several loci that are influenced by environmental factors (Bliss, 2010). Thus, recurrent selection is an efficient breeding technique used to increase the frequency of favorable alleles for these complex traits (Hallauer and Carena, 2012). Over the past decade, peach consumption per capita has decreased, most likely due to the inconsistent quality of the fruit in the market. This issue has spurred more effort in the fruit quality improvement in peach breeding programs throughout the world (Byrne, 2012; Crisosto and Kader, 2000). 
In general, phenological and fruit quality traits are important in the development of new peach cultivars. BD is a reliable estimate of chilling (de Souza, 1996), and is controlled by both chilling requirement and heat unit accumulation in low and medium chill environments (Rodriguez and Sherman, 1986). $\mathrm{RD}$ is affected by fruit crop load, cultural practices, weather conditions such as temperature, and genetics (Blake, 1932), and has been a focus of many breeding programs, particularly in the interest of developing earlier ripening cultivars (Byrne et al., 2012). FDP has been defined as the interval between BD and $\mathrm{RD}$ (Blake, 1932), and like RD, is influenced by both genetic and nongenetic factors (Weinberger, 1948).

Fruit size is an important characteristic for the development of new cultivars of peach. It is a function of both cell number and cell size (Scorza et al., 1991), and can be measured as both FW and FD (de Souza, 1996). Fruit size in peach appears to be quantitatively inherited. It has been suggested to exhibit dominance for smaller size fruit (Hesse, 1975), although this may be an illusion resulting from multiplicative action among traits controlling fruit size and mass (Hansche et al., 1972; Marini and Sowers, 1994). Blush is a quantitative trait and expressed during the final stage of fruit development (Bassi and Monet, 2008; Frett et al., 2014), and is affected by temperature, exposure to light, and other environmental factors (CorelliGrappadelli and Coston, 1991; de Souza, 1996). Blush has also been reported to be qualitatively controlled by several major genes in different germplasms (Beckman and Sherman, 2003). A major quantitative trait locus (QTL) which explains $72 \%$ of the variation in blush has also been reported on LG3 and located at the same genomic region of the candidate gene (PprMYB10) for skin and flesh coloration for peach (Frett et al., 2014) and other Rosaceae crops (Lin-Wang et al., 2010). A high percentage of red skin blush (blush) caused by the accumulation of anthocyanins is desirable for fresh market sale of peaches and nectarines in the United States (Beckman et al., 2005; Frett et al., 2014; Hesse, 1975).

Fruit shape is a function of the prominence of the pistil tip and the suture of the fruit. The shape is influenced by chilling accumulation and temperature during the early stages of fruit development (de Souza et al., 1998b; Topp and Sherman, 1989), and has traditionally been evaluated using a subjective scale (de Souza et al., 1998b; Rodriguez and Sherman, 1986; Sherman et al., 1984; Topp and Sherman, 1989).

Consumer acceptance and the organoleptic quality of fleshy fruits are most strongly affected by the content and composition of soluble sugars and organic acids (Crisosto and Crisosto, 2005; Dirlewanger et al., 1999). SSC is influenced by the amount of light received, canopy position, available water during fruit development, plant nutrition, thinning practices, position in the canopy, and temperature during fruit development (Westwood, 1993). TA and, in particular, the sugar/acid ratio, is an essential component of the organoleptic quality for fruits in the Rosaceae family (Crisosto and Crisosto, 2005). The major gene $D$ conditions low acidity in peach (Boudehri et al., 2009; Dirlewanger et al., 2009).

Several studies have focused on estimating heritability on a progeny-mean basis expressed as the proportion of genetic variance among a progeny to that of the phenotypic variance (Bernardo, 2010). Linear regression of offspring performance on mid parent performance has also been a useful method (Falconer, 1989), but is only an accurate estimate when the inbreeding coefficient is equal to zero (Fernandez and Miller,
1985). Although other methods of analysis based on variance components have been used, most require robust experimental designs with reciprocal crossing and replications, all of which have limited feasibility in fruit tree crops (de Souza, 1996). In contrast, random-effects models such as residual maximum likelihood (REML), which were first used in animal breeding (Henderson, 1984; Searle, 1971) and later in plant breeding (Huber, 1993; McCutchan et al., 1985; Tancred et al., 1995; Vileila-Morales et al., 1981), provide a robust analysis with the use of unbalanced and non-normal data in perennial plant species, as it maximizes the genetic variance likelihood after correcting for the fixed effects (Banks et al., 1985; Kouassi et al., 2009; Westfall, 1987). Studies by Vileila-Morales et al. (1981) and de Souza et al. (1998a, 1998b) have thus far been the only examples of using such a model for analyzing variance components in peach.

Moreover, for plant breeders and agronomists, a genotype plus genotype by environment (GGE) biplot is a beneficial tool for the graphical display of the $\mathrm{G} \times \mathrm{E}$ results. Research with a large number of genotypes evaluated across multiple locations and years makes the $\mathrm{G} \times \mathrm{E}$ and stability analysis a major challenge. Hence, the GGE biplot analysis is the appropriate tool for analyzing and interpreting data of multienvironment trials (Yan and Tinker, 2006). Likewise, correlations between traits also can be especially useful in plant breeding where the indirect selection may be applied for a trait. It is important to keep in mind that the implication of phenotypic correlation in a breeding program is limited by the fact that both genetic and environmental correlations are included (de Souza, 1996).

Overall, peach fruit quality traits are complex and affected by genetics, the environment, environmental interaction with genetics, and cultural practices (Byrne, 2005; Crisosto et al., 1997). Thus, in this study, we hypothesized that understanding genetic parameters, including variances, heritability, and relationships among traits will increase the peach breeding efficiency and help breeders in selecting for superior cultivars.

This research was conducted in low-medium chill earlyripening peach/nectarine germplasm with objectives to assess the effects of major genes (pantao and nectarine) on heritability for fruit quality traits, phenotypic correlation, and $\mathrm{G} \times \mathrm{E}$ for phenological traits (BD, RD, and FDP) and quality traits (FW and FD, blush, tip, shape, SSC, and TA) in high chill arid vs. low chill humid locations.

\section{Materials and Methods}

Plant materials. A total of 369 seedlings ( 2 to 4 years old) from nine $\mathrm{F}_{1}$ families (Supplemental Fig. 1) along with parental genotypes, were budded onto peach rootstocks 'Nemaguard' (P. persica $\times$ Prunus davidiana) and planted in College Station, TX, and Fowler, CA. The number of seedlings in each family ranged from 8 to 87 with an average size of 41 . Each site included one replicate of each seedling and three to four replicates of each parent.

Peach germplasm used in heritability study. The parents used reflect the diversity of germplasm used in the Low Chill Peach Breeding Program at TAMU over the past 35 years. These crosses were done to introgress high-quality and subacid qualities from the peach/nectarine germplasm developed at the U.S. Department of Agriculture (USDA) Stone Fruit Breeding Program (Parlier, CA) into low/medium chill germplasm by crossing them with low/medium chill peaches developed in 
Texas. The low chill, yellow-fleshed, acid-sweet peaches (TX2B136, 'Victor', and 'Tropic Zest Three') from the Texas program are mainly derived from Florida peach germplasm ('Tropic Beauty' and related selections) and medium chill peach germplasm developed in the USDA Stone Fruit Breeding program in Byron, GA ('Goldprince' and 'Springbrite'). The medium chill subacid white-fleshed cultivar, White Delight Two, is a result of crosses among Texas peaches and subacid white California material developed by Zaiger Genetics (Modesto, CA). The other materials are low to medium chill California peach and nectarines developed by the USDA (Parlier, CA) and selected for high quality early in the season. These include the subacid, whitefleshed pantao peach cultivar Galaxy that was developed via crossing materials from the New Jersey Agricultural Experiment Station Stone Fruit Breeding Program (New Brunswick, NJ) and P34-106, a derivative of the early medium chill nectarine, 'Armking'. The three subacid, yellow-fleshed nectarine selections (Y426-371, Y434-40, Y435-246) were developed from a diversity of germplasms, including 'Armking', and germplasms from the University of Florida (Gainesville), Rutgers University (New Brunswick, NJ), and Georgia USDA Stone Fruit Breeding Program (Byron, GA) (Supplemental Table 1).

Plot establishment and design. The College Station, TX, plot was randomized with one tree of each seedling and four replicates of each parent, whereas planting at the Fowler, CA, site was organized by progeny with three replicates of each parent. Trees at College Station were planted in staggered double rows, with $1.7 \mathrm{~m}$ between rows, and $0.67 \mathrm{~m}$ spacing within rows. Double rows were spaced $5 \mathrm{~m}$ apart. All trees were trained as a central leader. Trees in the Fowler plot were trained as a two-scaffold "Y" and spaced $1 \mathrm{~m}$ within rows and $4 \mathrm{~m}$ between rows. At each location, irrigation, fertilization, pest and weed control, pruning, and fruit thinning were done according to typical commercial practice.

Progenies and parents were evaluated at the two locations over 2 years: Fowler for 2011 and 2012; and College Station for 2012 and 2013. Fowler is located in the center of the San Joaquin Valley in central California and is ideal for peach production with a semiarid Mediterranean climate. College Station is located in east-central Texas with a sub-humid and warm temperate climate with mild winters and warm to hot, humid summers. The locations differ greatly in terms of climate, as College Station has more rainfall $(1000 \mathrm{~mm}$ for College Station; $284 \mathrm{~mm}$ for Fowler), humidity, cloudy days (College Station receives 27\% less sunlight per year), and warmer night temperatures during fruit development (Weather Underground, 2018). Also, College Station is much more likely to experience late spring freezes, extreme temperature swings, and fewer chilling hours $(\approx 540$ vs. $\approx 1090 \mathrm{~h})$ than the Fowler location. The College Station site also has poorer soil drainage and more sodic irrigation water than Fowler. These environmental factors make College Station less suitable for stone fruit production (Supplemental Table 2).

Data collection. Data were recorded on peach phenological and fruit quality traits from nine families (Supplemental Table 3) and eight parents (Supplemental Table 4). The collection of data at the Texas site was conducted by the TAMU Stone Fruit Breeding program. At the California site, data were collected by the staff of The Burchell Nursery (Fresno, CA) and Fruit Dynamics (Fresno, CA). Following harvest, the samples of five fruit were placed in paper bags at Fowler and in plastic zip-lock bags at College Station and placed in cold storage at 1 to $4{ }^{\circ} \mathrm{C}$ and evaluated within 1 week of collection. Pictures of the five-fruit samples were taken of the exterior of the fruit from four positions: top, cheek (one side), suture, and tip, as well as with transverse and equatorial bisecting cuts revealing the interior of the fruit.

Evaluations. BD was visually assessed in the field and recorded when $\approx 60 \%$ to $80 \%$ of the flowers had opened on each tree. The RD was determined by the presence of two to five soft fruit, at which point a sample of five firm mature fruit was collected for further evaluation of other traits. Fruit were visually inspected in the field for maturity weekly. Both BD and RD were converted into day of the year. FDP was calculated as the number of days between $\mathrm{BD}$ and RD. FW was recorded as the average FW in grams of a five-fruit sample. FD was measured in millimeters across the fruit cheek using a standard caliper based on the average of five fruit.

SSC (percent) was measured using a temperature-compensating refractometer. All measurements done by TAMU staff were done using a hand-held refractometer in which juice from individual fruit was measured and the average of three to five fruit was recorded. The Fruit Dynamics staff used a composite sample consisting of macerated fruit pulp that was centrifuged to collect the juice from a five-fruit sample. SSC data obtained from the two procedures proved to be highly correlated, thus data from the two samples were averaged.

TA was measured with $10 \mathrm{~g}$ of cheesecloth-filtered juice that was diluted with $30 \mathrm{~mL}$ of de-ionized water and placed in a 40-mL glass beaker. Samples were titrated with $0.1 \mathrm{~N} \mathrm{NaOH}$ to a $\mathrm{pH}$ of 8.1. A two-point calibration $\mathrm{pH}$ meter was used to determine the titration endpoint. Results were expressed as equivalents of anhydrous malic acid per $1000 \mathrm{~mL}$ of juice (eq $\mathrm{H}+/ 1000 \mathrm{~mL})$. The following conversion formula was used: $\mathrm{TA}=[(\mathrm{mL} \mathrm{NaOH} \times \mathrm{N} \times 0.067045) / \mathrm{mL}$ juice $] \times 1000$, where $\mathrm{mL} \mathrm{NaOH}$ is equal to milliliters $\mathrm{NaOH}$ used in the titration, $\mathrm{N}$ is the normality of $\mathrm{NaOH}$, and 0.067045 is a milliequivalent factor of malic acid in stone fruit. Samples from the Fowler site were evaluated by the Fruit Dynamics staff within 2 to $5 \mathrm{~d}$ in cold storage ( 4 to $5{ }^{\circ} \mathrm{C}$ ) after harvest. Juice from the same composite fruit sample used for soluble solids measurement was used for TA. At the College Station location, fruit were squeezed manually using a fruit press, and the resulting juice was stored in $60-\mathrm{mL}$ plastic containers at approximately $-20{ }^{\circ} \mathrm{C}$. The frozen samples were allowed to thaw at room temperature for $\approx 2 \mathrm{~h}$ before measurement.

Fruit red blush was evaluated for the amount of red pigmentation on the skin of the fruit using a 0 to 5 scale $[0=0 \%$ red coverage, $1=1 \%$ to $20 \%, 2=21 \%$ to $50 \%, 3=51 \%$ to $80 \%, 4=$ $81 \%$ to $99 \%, 5=100 \%$ (Frett et al., 2012)].

Fruit tip and shape were subjectively evaluated on a 1 to 9 scale. Tip ratings were based on the prominence of the tip at the distal end of the fruit and shape ratings assessed both tip and suture prominence in which $1=$ very large tip and/or suture, $3=$ large tip and/or suture, $5=$ moderate tip and/or suture, $7=$ mostly round with slight tip and/or suture, $9=$ round fruit. The most desirable shape would be round and symmetrical.

Statistical AnAlysis. All statistical analyses were performed using JMP Pro (version 13.2; SAS Institute, Cary, NC). Before statistical analyses, data were tested for normality using a Shapiro-Wilcox test. Data from all traits proved to be non-normally distributed. As transformations of the data did not 
improve its normality, the nontransformed data were used in all analyses.

A linear mixed model with REML procedure was used to estimate the additive genetic $\left(\sigma_{A}^{2}\right)$, nonadditive genetic $\left(\sigma_{d}^{2}\right)$, and $\mathrm{G} \times \mathrm{E}\left(\sigma_{g \times e}^{2}\right)$ variances for all traits. In the linear mixed model, the genotypes and genotype-environment interaction were considered as random effects and the environments as fixed effects. Because we ultimately considered two environments, only $1 \mathrm{df}$ was available for this term.

Parental [female parent (FP), pollen/male parent (PP)] variances were treated as $\sigma_{A}^{2}$, progeny variance was regarded as $\sigma_{d}^{2}$, and the sum of the parental and progeny variances were regarded as the total genotypic variance $\left(\sigma_{g}^{2}\right)$. The interaction of genotype (FP, PP, or progeny) and the environment was treated as $\sigma_{g \times e}^{2}$, and the phenotypic variance $\left(\sigma_{p}^{2}\right)$ was calculated as follows:

$$
\sigma_{p}^{2}=\sigma_{A}^{2}+\sigma_{d}^{2}+\sigma_{g \times e}^{2} / E,
$$

where $E=$ number of environments = 2 (de Souza et al., 1998a, 1998b; Holland et al., 2003; Liang et al., 2017; Wu et al., 2019). The size of the $\mathrm{G} \times \mathrm{E}$ variance relative to the genetic variance was assessed using the ratio $\sigma_{g \times e}^{2} / \sigma_{g}^{2}$ and further examined using the package GGEbiplots (Dumble, 2017) of $\mathrm{R}$ (version 4.0.2; R Foundation for Statistical Computing, Vienna, Austria). Broadsense heritability $\left(\mathrm{H}^{2}\right)$ estimates were calculated as follows:

$$
\mathrm{H}^{2}=\frac{\sigma_{g}^{2}}{\sigma_{g}^{2}+\frac{\sigma_{g \times e}^{2}}{E}}
$$

Narrow-sense heritability $\left(\mathrm{h}^{2}\right)$ estimates were calculated as follows:

$$
\mathrm{h}^{2}=\frac{\sigma_{A}^{2}}{\sigma_{g}^{2}+\frac{\sigma_{g \times e}^{2}}{E}}
$$

(Connor et al., 2005; Hallauer et al., 2010; Holland et al., 2003).

A bivariate model was used to estimate phenotypic correlations. Correlations were computed on a pairwise basis for all traits and between environments. The significance of correlation estimates was discussed based on the magnitude of the estimate because the sampling variances for the correlation estimates were not available. Thus, correlation estimate (r) $\geq$ 0.65 was considered strong to very strong; a correlation estimate between 0.50 and 0.64 was considered moderately strong; a correlation estimate between 0.30 and 0.49 was considered moderately weak (de Souza et al., 1998a).

\section{Results and Discussion}

Major Gene efFects on heritabiLITy. Previous reports have described the effects on fruit quality (size, shape, and blush) caused by the major genes that condition the pantao and nectarine forms of $P$. persica that could be due to pleiotropy or a strong linkage between loci conditioning the quality traits and the major genes (Wang, 2009; Wang et al., 2010; Wen et al., 1995a, 1995b; Wu et al., 2003a, 2003b). Because several of these progenies were segregating for one or both of these traits [25\% of the seedlings (Supplemental Fig. 1)], the analysis was run after removing both nectarine and pantao seedlings to assess their influence of these major genes on the heritability, for fruit size, blush, tip, shape, SSC, and TA traits. The results showed that $\mathrm{FW}, \mathrm{SSC}$, tip, and blush decrease approximately the same for $\mathrm{h}^{2}$ and $\mathrm{H}^{2}$ except for FD, which had a larger decrease in $\mathrm{h}^{2}$ vs. $\mathrm{H}^{2}$. There was an $\approx 41 \%$ to $86 \%$ decrease in additive genetic variance and an $\approx 14 \%$ to $122 \%$ decrease in nonadditive genetic variance for $\mathrm{FW}$ and FD (Table 1). Most of this effect was due to the elimination of the nectarine seedlings (data not shown). Because nectarines tend to be smaller than peaches (Oberle and Nicholson, 1953; Wang, 2009; Wang et al., 2010; Wen et al., 1995a, 1995b; Wu et al., 2003b), this decreased the genetic variability of the families. The broad-sense heritability for FW and FD, although lower, remained high. The original analysis (run with peach, nectarine, and pantao seedlings) indicated that the $h^{2}$ was higher (0.40) for FD than FW (0.16) (Table 1), whereas, with the removal of the seedlings expressing these major traits, both fruit size measurements have low $\mathrm{h}^{2}(0.09$ and 0.11 for FD and FW, respectively) (Table 1). The narrowsense heritability for blush was also lower (from 0.42 to 0.31). As anticipated, this was mainly due to the removal of the nectarine genotypes, as nectarines typically tend to have higher blush (Wang et al., 2010; Wen et al., 1995a, 1995b) than do peaches. Likewise, tip ratings showed a decrease in the estimated $\mathrm{h}^{2}$ (from 0.29 to 0.22 ). This was primarily due to the removal of the nectarine seedlings, as the nectarines tend to be rounder with less-pronounced tips (Wang, 2009), which decreased additive variance for this trait by $\approx 43 \%$. The $\mathrm{h}^{2}$ for SSC was also lower (from 0.16 to 0.03 ), as expected, this was mainly due to the removal of the nectarine and pantao genotypes, because nectarines and flat fruit showed a tendency of having higher SSC and total sugar content than peaches and round fruit, respectively (Cantín et al., 2009; Wang et al., 2010). This points to the importance of taking the effect of these major genes, which may have pleiotropic effects on the traits of interest, into account when assessing the genetic components of trait inheritance.

Phenotypic Correlations. The only strongly correlated traits were found between RD and FDP $(r=0.92)$ (Table 2), which reflects that RD is used to calculate FDP, and between FW and FD $(r=0.92)$, which are two ways of measuring fruit size, thus these were expected. In addition to that, a moderately weak correlation was observed between BD with FDP $(-0.46)$; however, earlier blooming does not necessarily result in a longer development period.

The bloom time in peach depends on the chill units and the growing degree hour accumulations to release from endodormancy and to complete full bloom, respectively. Thus, the lack of chilling might cause the low chill genotypes to bloom early, whereas the bloom of the higher chill genotypes was delayed by insufficient chilling. Likewise, the higher temperature at the early stage of growth can shorten the FDP and vice versa.

Negative correlations between fruit blush and both RD $(-0.41)$ and FDP $(-0.50)$, were moderately weak, as previously reported (de Souza et al., 1998b). This also may be the result of later-ripening fruit developing less skin color due to a denser tree canopy later in the season. Fruit positioned deep in the tree canopy have less blush (Bible and Singha, 1993; Lewallen and Marini, 2003). Both RD and FDP had positive and moderately weak correlations with FW (0.56 and 0.57$)$ and FD (0.53 and $0.56)$, respectively, suggesting that the longer a fruit is on the tree, the more resources can be sequestered and allocated to it. The correlations of RD and FDP with SSC (0.48 and 0.39, respectively) support earlier conclusions that it is more difficult 
Table 1. Variance component, broad-sense heritability $\left(\mathrm{H}^{2}\right)$, and narrow-sense heritability $\left(\mathrm{h}^{2}\right)$ for peach fruit quality traits of nine peach families evaluated at Fowler, CA, and College Station, TX, environments, comparing the effect of the removal of nectarine and pantao seedlings.

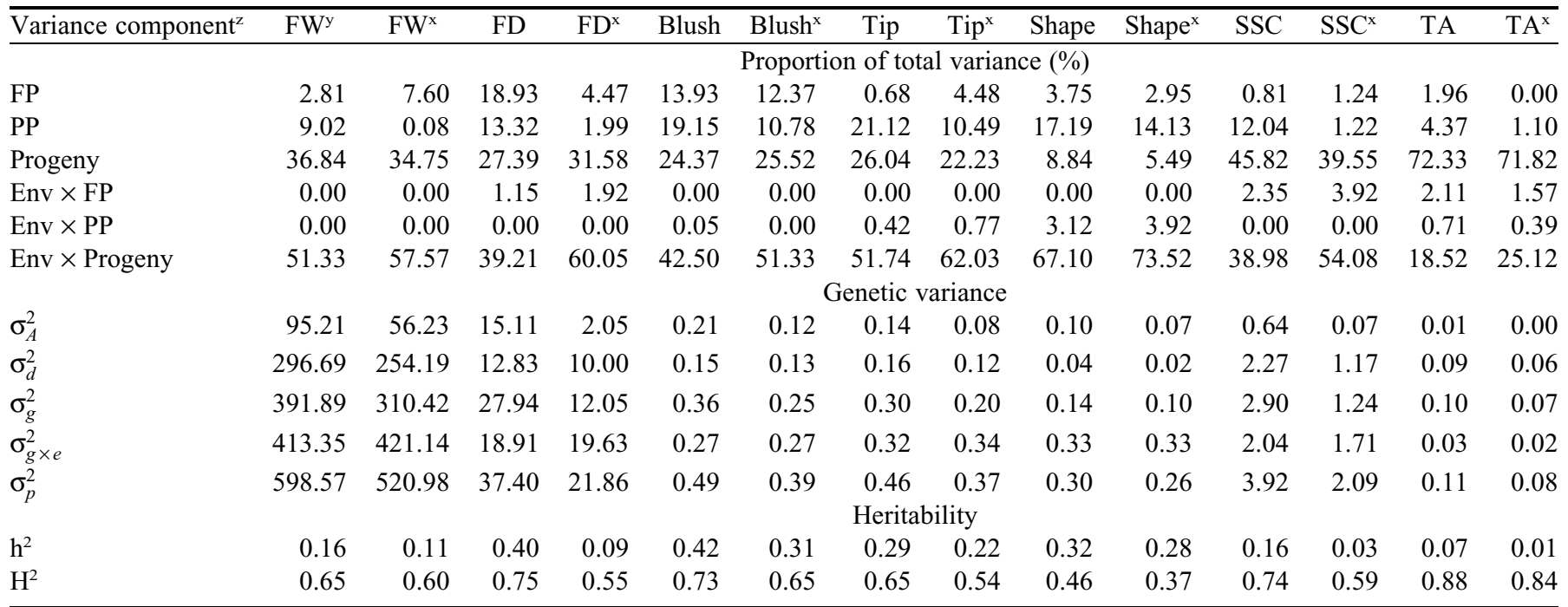

$\overline{\mathrm{z}} \mathrm{FP}=$ female parent; $\mathrm{PP}=$ pollen parent; Env = environment; $\sigma_{A}^{2}=$ parental variances; $\sigma_{d}^{2}=$ progeny variance; $\sigma_{g}^{2}=$ variance of parents and progeny; $\sigma_{g \times e}^{2}=$ variance of the interaction of genotype and environment, sum of the environment $\times \mathrm{FP}$, environment $\times \mathrm{PP}$, and environment $\times$ progeny; $\sigma_{p}^{2}$ (phenotypic variance $)=\left(\sigma_{A}^{2}+\sigma_{d}^{2}+\sigma_{g \times e}^{2} / E\right) ; \mathrm{h}^{2}($ narrow-sense heritability $)=\sigma_{A}^{2} / \sigma_{p}^{2} ; \mathrm{H}^{2}$ (broad-sense heritability) $=\left(\sigma_{A}^{2}+\sigma_{d}^{2}\right) / \sigma_{p}^{2} ; E=$ number of environments.

${ }^{\mathrm{y}} \mathrm{FW}=$ fruit weight in grams; $\mathrm{FD}=$ fruit diameter in millimeters; Blush $=$ visually based on coverage of red blush on skin using $0-5$ scale $(0=0 \%$ red coverage, $1=1 \%$ to $20 \%, 2=21 \%$ to $50 \%, 3=51 \%$ to $80 \%, 4=81 \%$ to $99 \%, 5=100 \%)$; Tip = fruit tip visually based on $1-9$ scale $(1=$ very large tip, $3=$ large tip, $5=$ medium protruding tip, $7=$ slight tip, $8=$ flat tip, $9=$ slightly indented tip); Shape $=$ fruit shape visually based on $1-9$ scale $(3=$ large tip and/or suture, $5=$ moderate tip and/or suture, $7=$ mostly round with slight tip and/or suture, $9=$ round fruit); SSC = percent soluble solids concentration; $\mathrm{TA}=$ titratable acidity expressed as $\mathrm{Eq} \mathrm{H}+/ 1000 \mathrm{~mL}$ of juice.

${ }^{\mathrm{x}}$ Analysis run without both nectarine and pantao seedlings.

Table 2. Phenotypic correlations among 10 peach phenological and fruit quality traits in nine peach families evaluated at Fowler, CA, and College Station, TX, environments without nectarine and pantao genotypes.

\begin{tabular}{|c|c|c|c|c|c|c|c|c|c|}
\hline Trait ${ }^{z}$ & $\mathrm{RD}$ & FDP & FW & FD & Blush & Tip & Shape & $\mathrm{SSC}$ & TA \\
\hline$\overline{\mathrm{BD}}$ & $-0.09^{\mathrm{NS}}$ & $-0.46^{* *}$ & $-0.24 * *$ & $-0.25 * *$ & $0.32 * *$ & $0.02^{\mathrm{NS}}$ & $-0.21 * *$ & $0.18^{* *}$ & $-0.22 * *$ \\
\hline $\mathrm{RD}$ & & $0.92 * *$ & $0.56^{* *}$ & $0.53 * *$ & $-0.41 * *$ & $0.06^{\mathrm{NS}}$ & $0.00^{\mathrm{NS}}$ & $0.48^{* *}$ & $-0.07^{\mathrm{Ns}}$ \\
\hline FDP & & & $0.57 * *$ & $0.56^{* *}$ & $-0.50 * *$ & $0.04^{\mathrm{NS}}$ & $0.07^{\mathrm{Ns}}$ & $0.39 * *$ & $0.01^{\mathrm{NS}}$ \\
\hline FW & & & & $0.92 * *$ & $-0.32 * *$ & $0.05^{\mathrm{Ns}}$ & $0.13 * *$ & $0.05^{\mathrm{NS}}$ & $-0.04^{\mathrm{Ns}}$ \\
\hline FD & & & & & $-0.28 * *$ & $0.12 * *$ & $0.12 * *$ & $0.06^{\mathrm{NS}}$ & $-0.05^{\mathrm{Ns}}$ \\
\hline Blush & & & & & & $0.11 *$ & $0.02^{\mathrm{Ns}}$ & $-0.12 * *$ & $-0.16^{* *}$ \\
\hline Tip & & & & & & & $0.26^{* *}$ & $0.11 *$ & $-0.15^{* *}$ \\
\hline Shape & & & & & & & & $0.03^{\mathrm{Ns}}$ & $0.07^{\mathrm{Ns}}$ \\
\hline SSC & & & & & & & & & $-0.25 * *$ \\
\hline
\end{tabular}

$\overline{\mathrm{z}} \mathrm{BD}=$ bloom date in day of the year; $\mathrm{RD}=$ ripe date in day of the year; FDP $=$ fruit development in days; FW = fruit weight in grams; FD = fruit diameter in millimeters; Blush $=$ visually based on coverage of red blush on skin using $0-5$ scale $(0=0 \%$ red coverage, $1=1 \%$ to $20 \%, 2=21 \%$ to $50 \%$, $3=51 \%$ to $80 \%, 4=81 \%$ to $99 \%, 5=100 \%)$; Tip = fruit tip visually based on $1-9$ scale $(1=$ very large tip, $3=$ large tip, $5=$ medium protruding tip, $7=$ slight tip, $8=$ flat tip, $9=$ slightly indented tip); Shape $=$ fruit shape visually based on $1-9$ scale $(3=$ large tip and/or suture, $5=$ moderate tip and/or suture, $7=$ mostly round with slight tip and/or suture, $9=$ round fruit); SSC = percent soluble solids concentration; $\mathrm{TA}=$ titratable acidity expressed as $\mathrm{Eq} \mathrm{H}^{+} / 1000 \mathrm{~mL}$ of juice.

NS, * **Nonsignificant or significant at $P \leq 0.05$ or 0.01 , respectively.

to select for high sugar progeny that are earlier ripening or have a short development period (de Souza et al., 1998b; Wu et al., 2003b).

Overall, the correlation of RD with several traits could have resulted from either the tight linkage between the RD locus and other QTLs or the pleiotropic effects of the maturity date locus on other fruit quality traits where most of the QTLs of these traits colocalized with the RD QTL on LG4 in peach (Eduardo et al., 2011; Hernández Mora et al., 2017; Pirona et al., 2013) or other Prunus species (Dirlewanger et al., 2012).

VARIANCE COMPONENT AND HERITABILITY. Substantial variability among progenies was observed for all the traits evaluated and was comparable to, if not greater than, the parents when considering both range and variance (Supplemental Tables 3 and 4).

The BD was moderately heritable $\left(\mathrm{h}^{2}=0.46\right)$ (Table 3$)$, which was not unexpected given previous heritability estimates $\left(\mathrm{h}^{2}=0.39\right.$ to 0.92$)$ (de Souza et al., 1998b; Hansche et al., 1972; Hernández Mora et al., 2017) and wide range of bloom dates for the parents (20 to $70 \mathrm{~d}$ ) (Supplemental Table 4).

Although $\mathrm{h}^{2}$ for $\mathrm{RD}(0.79$ to 0.94 ) and FDP (0.73 to 0.98$)$ was previously reported (de Souza et al., 1998b; Hansche and Beres, 1980; Hansche et al., 1972; Hernández Mora et al., 2017; Vileila-Morales et al., 1981), in this study, both of the RD and FDP had low $\mathrm{h}^{2}$ (0.03 and 0.06 , respectively) and high $\mathrm{H}^{2}(0.91)$ (Table 3 ). This low additive and high nonadditive heritability suggest major gene action in this germplasm, as has been previously suggested (Hesse, 1975; Vileila-Morales et al., 1981). The lower heritability that was observed in the study 
Table 3. Variance component, broad-sense heritability $\left(\mathrm{H}^{2}\right)$, and narrow-sense heritability $\left(\mathrm{h}^{2}\right)$ for three peach phenological traits evaluated at Fowler, CA, and College Station, TX, environments without nectarine and pantao genotypes.

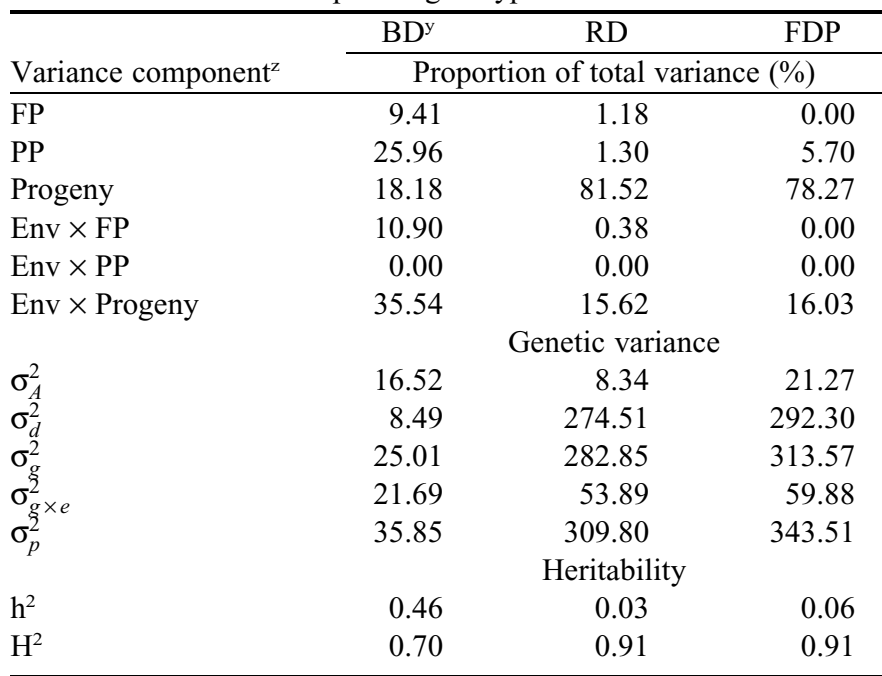

${ }^{\mathrm{z}} \mathrm{FP}=$ female parent; $\mathrm{PP}=$ pollen parent; Env = environment; $\sigma_{A}^{2}=$ parental variances; $\sigma_{d}^{2}=$ progeny variance; $\sigma_{g}^{2}=$ variance of parents and progeny; $\sigma_{g \times e}^{2}=$ variance of the interaction of genotype and environment, sum of the environment $\times \mathrm{FP}$, environment $\times \mathrm{PP}$, and environment $\times$ progeny; $\sigma_{p}^{2}$ (phenotypic variance $)=$ $\left(\sigma_{A}^{2}+\sigma_{d}^{2}+\sigma_{g \times e}^{2} / E\right) ; \mathrm{h}^{2}$ (narrow-sense heritability) $=\sigma_{A}^{2} / \sigma_{p}^{2} ; \mathrm{H}^{2}$ (broad-sense heritability) $=\left(\sigma_{A}^{2}+\sigma_{d}^{2}\right) / \sigma_{p}^{2} ; E=$ number of environments.

${ }^{\mathrm{y}} \mathrm{BD}=$ bloom date in day of the year; $\mathrm{RD}=$ ripe date in day of the year; $\mathrm{FDP}=$ fruit development period in days.

Table 4. Pearson correlation coefficients between two environments (Fowler, CA, and College Station, TX) measured for 10 traits in nine peach families without nectarine and pantao (flat shape) genotypes.

\begin{tabular}{lc}
\hline Trait $^{z}$ & Correlation coefficient \\
\hline BD & $0.78^{* *}$ \\
RD & $0.87^{* *}$ \\
FDP & $0.87^{* *}$ \\
FW & $0.61^{* *}$ \\
FD & $0.62^{* *}$ \\
Blush & $0.63^{* *}$ \\
Tip & $0.61^{* *}$ \\
Shape & $0.45^{* *}$ \\
SSC & $0.76^{* *}$ \\
TA & $0.95^{* *}$
\end{tabular}

$\overline{\mathrm{z}} \mathrm{BD}=$ bloom date in day of the year; $\mathrm{RD}=$ ripe date in day of the year; $\mathrm{FDP}=$ fruit development period in days; $\mathrm{FW}=$ fruit weight in grams; $\mathrm{FD}=$ fruit diameter in millimeters; Blush $=$ visually based on coverage of red blush on skin using $0-5$ scale $(0=0 \%$ red coverage, $1=1 \%$ to $20 \%, 2=21 \%$ to $50 \%, 3=51 \%$ to $80 \%, 4=81 \%$ to $99 \%, 5=100 \%$ ); Tip $=$ fruit tip visually based on $1-9$ scale $(1=$ very large tip, $3=$ large tip, $5=$ medium protruding tip, $7=$ slight tip, $8=$ flat tip, $9=$ slightly indented tip); Shape $=$ fruit shape visually based on $1-9$ scale $(3=$ large tip and/or suture, $5=$ moderate tip and/or suture, $7=$ mostly round with slight tip and/or suture, $9=$ round fruit); $\mathrm{SSC}=$ percent soluble solids concentration; TA = titratable acidity expressed as Eq $\mathrm{H}+/ 1000 \mathrm{~mL}$ of juice.

** Significant at $P \leq 0.01$.
Table 5. Genetic variance $\left(\sigma_{g}^{2}\right)$, genotype by environment variance $\left(\sigma_{g \times e}^{2}\right)$, and the genotype by environment variance relative to the genetic variance $\left(\sigma_{g \times e}^{2} / \sigma_{g}^{2}\right)$ assessed for 10 traits in nine peach families without nectarine and pantao (flat shape) genotypes.

\begin{tabular}{lrrc}
\hline Trait $^{z}$ & \multicolumn{1}{c}{$\sigma_{g}^{2}$} & $\sigma_{g \times e}^{2}$ & $\sigma_{g \times e}^{2} / \sigma_{g}^{2}$ \\
\hline BD & 25.01 & 21.69 & 0.87 \\
RD & 282.85 & 53.89 & 0.19 \\
FDP & 313.57 & 59.88 & 0.19 \\
FW & 310.42 & 421.14 & 1.36 \\
FD & 12.05 & 19.63 & 1.63 \\
Blush & 0.25 & 0.27 & 1.05 \\
Tip & 0.20 & 0.34 & 1.69 \\
Shape & 0.10 & 0.33 & 3.43 \\
SSC & 1.24 & 1.71 & 1.38 \\
TA & 0.07 & 0.02 & 0.37
\end{tabular}

${ }_{\mathrm{z}}^{\mathrm{BD}}=$ bloom date in day of the year; $\mathrm{RD}=$ ripe date in day of the year; $\mathrm{FDP}=$ fruit development in days; FW = fruit weight in grams; FD = fruit diameter in millimeters; Blush = visually based on coverage of red blush on skin using $0-5$ scale $(0=0 \%$ red coverage, $1=1 \%$ to $20 \%, 2=$ $21 \%$ to $50 \%, 3=51 \%$ to $80 \%, 4=81 \%$ to $99 \%, 5=100 \%$ ); Tip = fruit tip visually based on $1-9$ scale $(1=$ very large tip, $3=$ large tip, $5=$ medium protruding tip, $7=$ slight tip, $8=$ flat tip, $9=$ slightly indented tip); Shape = fruit shape visually based on 1-9 scale (3 = large tip and/ or suture, $5=$ moderate tip and/or suture, $7=$ mostly round with slight tip and/or suture, $9=$ round fruit); SSC $=$ percent soluble solids concentration; $\mathrm{TA}=$ titratable acidity expressed as $\mathrm{Eq} \mathrm{H}^{+} / 1000 \mathrm{~mL}$ of juice.

compared with the previous studies could be attributed to the poor environmental conditions.

Fruit size, measured as FW and FD, exhibited low (0.16) to moderate $(0.40) \mathrm{h}^{2}$, which decreased more after eliminating nectarine and pantao fruit ( 0.11 and 0.09 , respectively) (Table 1). Thus, the estimates of $h^{2}$ for FD and FW were generally lower than previously reported $(0.29-0.60)$ (de Souza et al., 1998b; Fresnedo-Ramírez et al., 2015; Frett, 2016; Hansche, 1986; Hansche et al., 1972), especially if considering only the peach seedlings, despite displaying substantial variability among families, in many of which transgressive segregation was observed (Supplemental Tables 3 and 4). As was the case with $\mathrm{RD}$ and FDP, $\mathrm{H}^{2}$ was high for FD (0.55 to 0.75$)$ and FW (0.60 to 0.65 ) (Table 1$)$, indicating important nonadditive effects for these traits.

These changes in heritability were not surprising, as heritability is known as population-specific and is influenced by multiple factors, including the amount of genetic variation present in a population, sample size, experimental design, pedigree structure, the statistical procedure conducted, and the environment in which plants are grown (Visscher et al., 2008).

Blush showed moderate additive inheritance $\left(\mathrm{h}^{2}=0.31\right.$ to 0.42 ) in both analyses (with and without nectarine and pantao) (Table 1), as was previously reported (de Souza et al., 1998b; Hansche and Beres, 1980; Hernández Mora et al., 2017). However, the high $\mathrm{H}^{2}$ (0.65 to 0.73 ) supports the notion that a few major genes are affecting the accumulation of anthocyanins in the peach skin (Wen et al., 1995a, 1995b).

Fruit tip and shape showed moderately low $\mathrm{h}^{2}(0.22$ to 0.29 and 0.28 to 0.32 ) in both analyses, respectively (Table 1), which was lower than previous estimates $(0.43$ to 0.45$)$ by de Souza et al. (1998b). The moderate $\mathrm{H}^{2}$ (0.37 to 0.46 and 0.54 to 0.65$)$ indicates substantial environmental effects on these traits and moderate to high $\mathrm{G} \times \mathrm{E}$ interaction. 

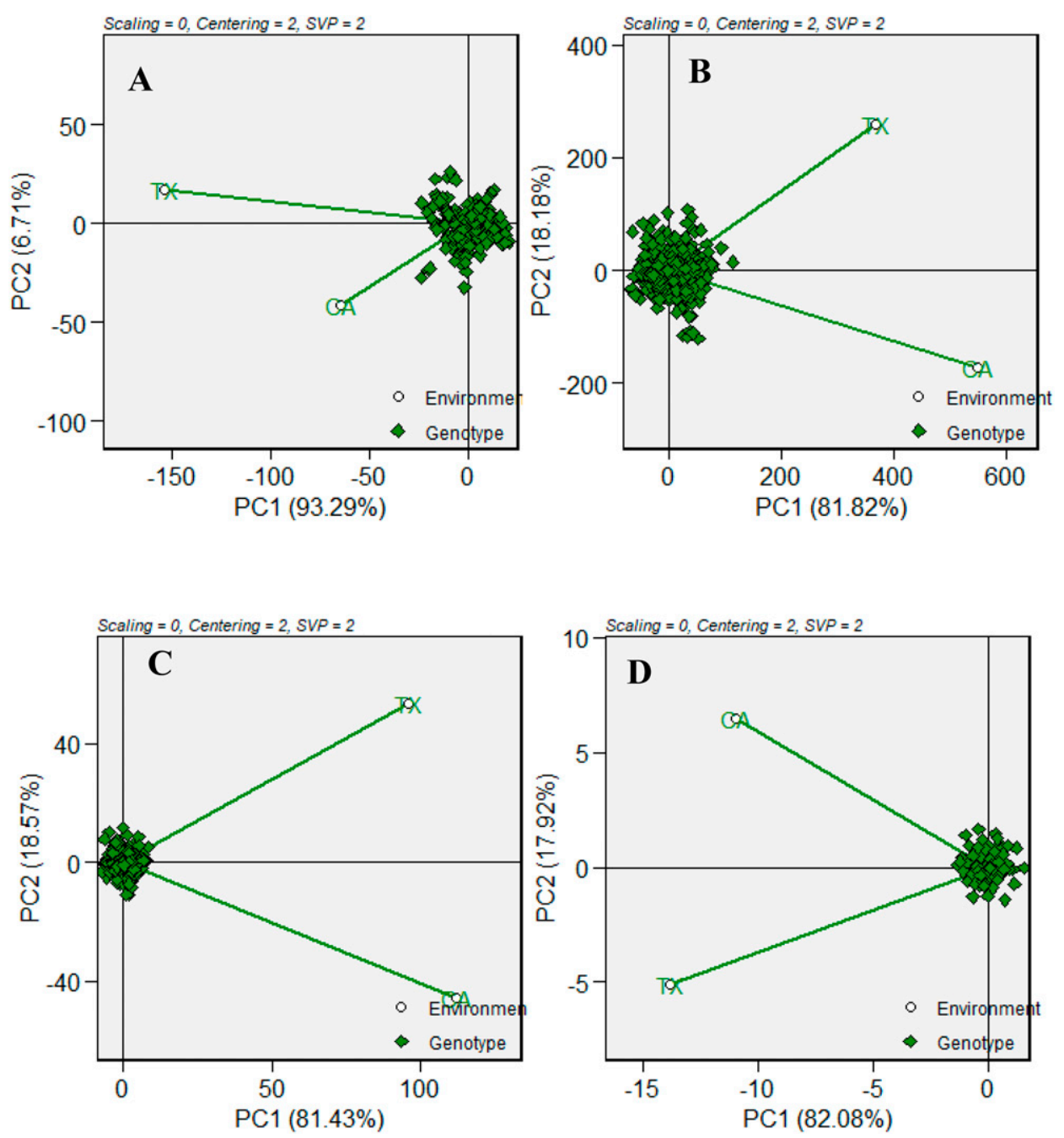

Fig. 1. Genotype plus genotype $\times$ environment (GGE) biplot representing the discrimination and representativeness of environments for the bloom date (A), fruit weight (B), fruit diameter (C), and blush (D) of peach genotypes (without nectarine and pantao) grown in Fowler, CA, and College Station, TX, environments. Principal component 1 and 2 ( $\mathrm{PC} 1$ and $\mathrm{PC} 2$ ) describe the proportion of total GGE variation accounted for primary and secondary effects.

The range for SSC varied widely from $7.2 \%$ to $21.7 \%$ (Supplemental Table 3). A greater variability was observed among progeny than parents (Supplemental Table 4), as reflected by the wider range among progeny. The low $\mathrm{h}^{2}$ estimate for SSC in both analyses ( 0.16 and 0.03 , respectively), was higher than that of 0.01 reported by Hansche et al. (1972), but was considerably lower than other estimates $(0.33,0.43,0.72)$ (Brooks et al., 1993; de Souza et al., 1998b). $\mathrm{H}^{2}$ was much higher (0.74) (Table 1), supporting the conclusion that sugar content in peach is affected by major genes (Cantín et al., 2009; Dirlewanger et al., 2009; Quilot-Turion and Genard, 2009). The distribution of SSC appeared to be skewed $(+0.6$ and +1.1 for California and Texas, respectively) toward the lower end (Supplemental Fig. 2), suggesting dominance for low sugar in these populations. Nevertheless, some genetic improvement for this trait should be possible, given the observation of transgressive segregation in some progenies.

A substantial amount of variability was associated with TA, as indicated by the range $\left(0.2\right.$ to $2.2 \mathrm{~mL} \mathrm{Eq} \mathrm{H}^{+} / 1000 \mathrm{~mL}$ of juice), with a mean of 0.7 (Supplemental Table 3). Both the range and variance among progeny were comparable to that of the parents for this trait (Supplemental Table 4). TA showed very low additive inheritance in the original analysis and after eliminating nectarine and pantao $\left(\mathrm{h}^{2}=0.07\right.$ and 0.01 , respectively), which was lower than the previously reported $(\leq 0.19)$ (Hansche, 1986; Hansche and Beres, 1980; Hansche et al., 1972) to moderate (0.31) (de Souza et al., 1998b) estimates. The estimate of $\mathrm{H}^{2}$ was high (0.88) (Table $1)$, reflecting the fact that these populations were segregating for the $D$-gene, which conditions a low level of acidity (Boudehri et al., 2009; Dirlewanger et al., 1999). The existence of this major gene in these populations is evident in the bimodal distribution associated with this trait (Supplemental Fig. 3). Although the selection for either low- or high-acid fruit is straightforward, the selection of the acidity levels within each extreme acidity class is more challenging.

Again, the low heritability for most of the traits in this study is not unexpected, because parental germplasm used either commercial cultivars or advanced selections that had been selected for desirable traits. Hence, selection alters the heritability of the traits as a result of changes in gene frequencies (Falconer, 1989; Hansche, 1983). Heritability of the same trait can be changed across populations over time, based on the definition, due to several factors, including changes in the genetic variance because of change in allele frequencies as a result of selection/inbreeding or introduction of new variants into the population throughout mutation/ migration, as well as environmental variance, which may vary across populations (Visscher et al., 2008).

In general, given the appreciable variability, moderate $\mathrm{h}^{2}$ and moderate to high $\mathrm{H}^{2}$ of these traits, breeders can achieve rapid genetic gain through the selection of parents based on phenotype and recurrent mass selection (Topp and Sherman, 2000). Intrapopulation recurrent selection method has been used to improve the quantitative traits to increase the frequencies of desirable alleles in the population, while maintaining a high degree of heterozygosity. This is the most common improvement method that has been applied in peach breeding programs, which allows combining several quantitative traits (Scorza et al., 1985).

However, the incorporation of marker-assisted selection (MAS) tools can provide breeders with more informed decisions and efficiency on selecting parents with desirable genotypes through marker-assisted parent selection, selecting 

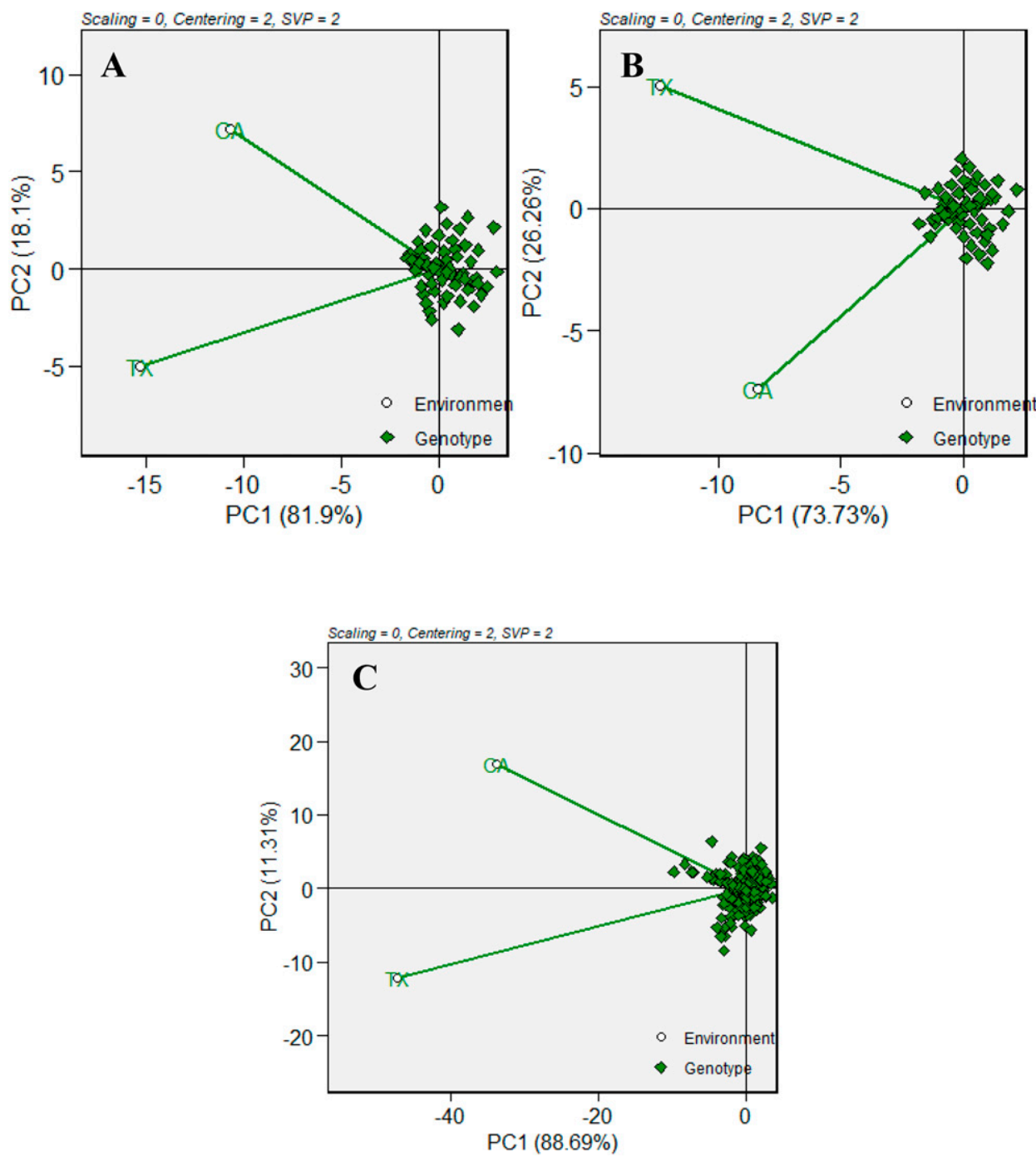

Fig. 2. Genotype plus genotype $\times$ environment (GGE) biplot representing the discrimination and representativeness of environments for the fruit tip (A), fruit shape (B), and soluble solids concentration (C) of peach genotypes (without nectarine and pantao) grown in Fowler, CA, and College Station, TX, environments. Principal component 1 and 2 (PC1 and PC2) describe the proportion of total GGE variation accounted for primary and secondary effects.

favorable crosses with efficient combining abilities through marker-assisted cross selection, and culling of undesirable seedlings of a given trait before growing them in the field through marker-assisted seedling selection. Thus, MAS tools will accelerate the traditional breeding methods and save resources for developing high-quality peach cultivars (Bliss, 2010; Byrne, 2005; Collard et al., 2005; Edge-Garza et al., 2015; Ru et al., 2015).

$\mathbf{G} \times \mathbf{E}$ eFFECTs. Understanding the $\mathrm{G} \times \mathrm{E}$ interaction is important for the selection efficacy in a plant breeding program. $\mathrm{G} \times \mathrm{E}$ implies the differential performance of genotypes across environments that arises from the variations in the genotype sensitivities to the environmental conditions. The analysis was done considering the two major gene effects (pantao and nectarine).

$\mathrm{RD}, \mathrm{FDP}$, and TA showed very high $\mathrm{H}^{2}(0.91,0.91$, and 0.84 , respectively) (Tables 1 and 3), strong correlations between environments $(0.87,0.87$, and 0.95 , respectively) (Table 4$)$, and minimal $\sigma_{g \times e}^{2} / \sigma_{g}^{2}(0.19,0.19$, and 0.37 , respectively) (Table 5), whereas the other traits, BD, FW, FD, blush, tip, and SSC, showed high to moderate $\mathrm{H}^{2}(0.70$ to 0.54$)$ (Tables 1 and 3 ), strong to moderate correlation coefficient among environments $(0.78$ to 0.61$)$ (Table 4$)$, and a moderate $\mathrm{G} \times \mathrm{E}\left(\sigma_{g \times e}^{2} / \sigma_{g}^{2}\right.$ between 0.87 and 1.69) (Table 5). The higher $\mathrm{G} \times \mathrm{E}$ effect for these traits is further supported by the high PC2 values (ranged from $6.7 \%$ to $18.6 \%$ ) (Supplemental Table 5), implying that the environments did discriminate among the populations for these traits. Finally, the maximal $\mathrm{G} \times \mathrm{E}$ effect was noticed for shape $\left(\sigma_{g \times e}^{2} / \sigma_{g}^{2}=3.43\right)($ Table 5), and is supported by the lowest correlation between the environments $(0.45)$ (Table 4) and the highest PC2 value (26.3\%) (Supplemental Table 5), indicating there is a discrimination between the two environments for shape.

For $\mathrm{BD}$ and SSC, the sharper angle and less distance were observed between California and Texas as compared with other traits and is supported by a stronger correlation between these environments (0.78 and 0.76) (Table 4), whereas less sharp angles, the wide distance between the two environments, and weak correlation was observed in shape (0.45). The distance between the two environments explains their similarity or dissimilarity in discriminating the genotypes (Yan and Tinker, 2006).

GGE biplot showed the vectors were different in length for $\mathrm{BD}$ in which the Texas environment had longer vector than California and was discriminating the genotypes (Fig. 1). This illustrated the higher variability among the families in College Station, TX (29 to 75 d) compared with Fowler, CA (37 to 54 d) (Supplemental Table 6). This was expected, as BD was strongly affected by the temperature, as bloom began earlier in College Station because of warmer January $\left(12.8\right.$ vs. $\left.9.1{ }^{\circ} \mathrm{C}\right)$, February $\left(14.4\right.$ vs. $\left.10.7^{\circ} \mathrm{C}\right)$, and March $\left(17.8\right.$ vs. $\left.13.3{ }^{\circ} \mathrm{C}\right)$ temperatures than Fowler. Besides, some of the higher chill genotypes had delayed bloom in the lower chill College Station site as compared with Fowler $\approx \approx 540$ vs. $\approx 1087 \mathrm{~h}$ ) (Supplemental Table 2).

GGE biplot for FW and FD showed that the length of the environmental vector of California was longer than that of Texas (Fig. 1), indicating that California was more capable of discriminating the families than Texas. As anticipated, the fruit was $\approx 29 \%$ heavier at the more favorable Fowler, CA, site as compared with College Station, TX (Supplemental Table 6). The trend for smaller size observed at College Station, TX, as 
compared with Fowler, CA, was due to the warmer temperatures during fruit development (Supplemental Table 2), resulting in a shorter FDP and smaller size (Supplemental Table 6). The fact that the families studied tended to be early ripening might have influenced this, as early-ripening peaches tend to have smaller size compared with medium- to lateripening peaches (Fresnedo-Ramírez et al., 2015; Frett, 2016). This is supported by the moderate correlations between RD/ FDP and fruit size (FW/FD) in this study (Table 2) and earlier studies (Dirlewanger et al., 1999; Lopez and Dejong, 2007; Ruiz and Egea, 2008). For FW and FD, the differential response of families to the environment in which they are grown was not linked to any specific parents (Supplemental Table 7). Given the moderate size of this $\mathrm{G} \times \mathrm{E}$ interaction, it is not a major impediment for the selection for large fruit size. As with any genotype, it is essential to test it in the region in which it is to be grown to make the best decision on whether to use it or not.

For blush, the California site was a more discriminatory environment compared with the Texas site (Fig. 1). Generally, fruit in Texas had more blush on the skin than California (3.3 vs. 2.9) (Supplemental Table 6). Five of the nine families had significantly higher blush in Texas compared with California (Supplemental Table 7) and were not related to specific parent(s). This quantitative trait is affected by exposure to sunlight and other environmental factors (Corelli-Grappadelli and Coston, 1991; de Souza, 1996).

The fruit tip and shape trait biplots showed that Texas discriminated the genotypes differently from the California environment (Fig. 2). In general, mean fruit tip and fruit shape ratings were higher (fruit was rounder) in California as compared with Texas (Supplemental Table 6). Both fruit tip and shape generally become less desirable when the fruit is exposed to lower chilling conditions and warm temperatures during the early part of fruit development (de Souza et al., 1998b; Topp et al., 1993). A comparison of mean monthly temperatures of the two locations revealed that temperatures were much warmer at College Station, TX, for 2 years than the Fowler, CA, site during bloom and early fruit development (Supplemental Table 2), which explains the lower fruit tip/shape ratings for Texas compared with California (Supplemental Table 6). The selection for tip or shape for peaches (neither nectarine nor flat types) should be done on a regional basis with the best differentiation possible under the warmer climatic conditions that favor larger tip and suture development.

Supplemental Table 8 shows that most tip ratings were comparable (not significant) except for two families (TX2B136 $\times$ 'Galaxy' and 'Victor' $\times$ Y426-371) in which the tip ratings were higher at Texas vs. California. For shape, the interaction resulted from two families ('White Delight Two' $\times$ Y434-40 and 'Victor' $\times$ Y435-246), which deviated and behaved differently; however, the shape rating was lower at College Station, TX.

GGE biplot for SSC indicated that families responded differently across environments, as we observed the difference in the length of the environmental vectors (Fig. 2). Texas showed more SSC than California (12.3 vs. 11.0) (Supplemental Table 6), likely due to greater environmental stresses affecting this site, such as shallow and droughty soils as well as smaller fruit sizes, all of which can result in higher SSC (Veihmeyer and Hendrickson, 1949). This trait is strongly influenced by numerous environmental factors, including tem- perature, canopy position, water availability, crop load, and agricultural practices during the FDP (Crisosto et al., 1997). Five of the nine families showed higher SSC in Texas compared with California, two families of which had Y434-40 as a male parent and three with 'Victor' as a female parent, resulting in the interaction (Supplemental Table 8). The responses of these families across environments could not be explained in this study; however, the preceding parents along with the Y426-371 parent are characterized by a short FDP (Supplemental Table 1). More work needs to be done to determine the reason and importance of this interaction.

\section{Conclusions}

All traits evaluated were associated with large phenotypic variability, which is necessary for genetic improvement. Removal of pantao and nectarine fruits from the analysis resulted in a lower $\mathrm{h}^{2}$ and $\mathrm{H}^{2}$ for FW, FD, blush, tip, and SSC traits. This emphasizes the importance of taking into account the effect of major genes segregating within populations in developing breeding strategies. A strong correlation was found between RD and FDP and between FW and FD, suggesting that either measure is equally effective. RD and FDP were moderately correlated with FW, FD, blush, and SSC, which may be explained by either presence of the pleiotropic effect of the ripening date gene on several quality traits or there is a strong linkage between the ripening date locus and QTLs of these traits.

All but three traits (RD, FDP, and TA) showed GXE and had differential responses for genotype across environments, suggesting that, for these traits, selection for or against these traits should be practiced only where the plants are intended to be grown. BD, FD, blush, fruit tip, and shape traits showed moderately heritable on a narrow-sense basis, whereas RD, FDP, FW, SSC, and TA were associated with low additive heritability. $\mathrm{H}^{2}$ estimates for these traits were high, suggesting an important nonadditive genetic component.

\section{Literature Cited}

Banks, B.D., I.L. Mao, and J.P. Walter. 1985. Robustness of the restricted maximum likelihood estimator derived under normality as applied to data with skewed distributions. J. Dairy Sci. 68:17851792, doi: 10.3168/jds.S0022-0302(85)81028-6.

Bassi, D. and R. Monet. 2008. Botany and taxonomy, p. 1-36. In: D. Layne and D. Bassi (eds.). The peach, botany, production and uses. CABI, Wallingford, UK. doi: 10.1079/9781845933869.0061.

Beckman, T.G., J. Rodriguez Alcazar, W.B. Sherman, and D.J. Werner. 2005. Evidence for qualitative suppression of red skin color in peach. HortScience 40:523-524, doi: 10.21273/HORTSCI. 40.3.523.

Beckman, T.G. and W.B. Sherman. 2003. Probable qualitative inheritance of full red skin color in peach. HortScience 38:1184-1185, doi: 10.21273/HORTSCI.38.6.1184.

Bernardo, R.N. 2010. Breeding for quantitative traits in plants. Stemma Press, Woodbury, MN. doi: 10.2135/cropsci2003.1578.

Bible, B.B. and S. Singha. 1993. Canopy position influences CIELAB coordinates of peach color. HortScience 28:992-993, doi: 10.21273/ HORTSCI.28.10.992.

Blake, M.A. 1932. The J.H. Hale as a parent in peach crosses. Proc. Amer. Soc. Hort. Sci. 29:131-136.

Bliss, F.A. 2010. Marker-assisted breeding in horticultural crops. Acta Hort. 859:339-350, doi: 10.17660/ActaHortic.2010.859.40.

Boudehri, K., M.A. Belka, G. Cardinet, G. Capdeville, C. Renaud, Y. Tauzin, E. Dirlewanger, A.M. Dirlewanger, C. Troadec, D. Jublot, 
M. Caboche, and A. Bendahmane. 2009. Toward the isolation of the $D$ gene controlling the acidity of peach fruit by positional cloning. Acta Hort. 814:507-510, doi: 10.17660/ActaHortic.2009.814.85.

Brooks, S.J., J.N. Moore, and J.B. Murphy. 1993. Quantitative and qualitative changes in sugar content of peach genotypes [Prunus persica (L.) Batsch]. J. Amer. Soc. Hort. Sci. 118:97-100, doi: 10.21273/JASHS.118.1.97.

Byrne, D.H. 2005. Trends in stone fruit cultivar development. HortTechnology 15:494-500, doi: 10.21273/HORTTECH.15. 3.0494 .

Byrne, D.H. 2012. Trends in fruit breeding, p. 3-36. In: M.L. Badenes and D.H. Byrne (eds.). Fruit breeding. Springer, Boston, MA. doi: 10.1007/978-1-4419-0763-9_1.

Byrne, D.H., M.B. Raseira, D. Bassi, M.C. Piagnani, K. Gasic, G.L. Reighard, M.A. Moreno, and S. Pérez. 2012. Peach, p. 505-569. In: L.M. Badenes and H.D. Byrne (eds.). Fruit breeding. Springer, Boston, MA. doi: 10.1007/978-1-4419-0763-9_14.

Cantín, C.M., Y. Gogorcena, and M.A. Moreno. 2009. Analysis of phenotypic variation of sugar profile in different peach and nectarine Prunus persica (L.) Batsch breeding progenies. J. Sci. Food Agr. 89:1909-1917, doi: 10.1002/jsfa.3672.

Cevallos-Casals, B.A., D.H. Byrne, W.R. Okie, and L. CisnerosZevallos. 2006. Selecting new peach and plum genotypes rich in phenolic compounds and enhanced functional properties. Food Chem. 96:273-280, doi: 10.1016/j.foodchem.2005.02.032.

Collard, B.C.Y., M.Z.Z. Jahufer, J.B. Brouwer, and E.C.K. Pang. 2005. An introduction to markers, quantitative trait loci (QTL) mapping and marker-assisted selection for crop improvement: The basic concepts. Euphytica 142:169-196, doi: 10.1007/s10681-005-1681-5. Connor, A., M. Stephens, H. Hall, and P. Alspach. 2005. Variation and heritabilities of antioxidant activity and total phenolic content estimated from a red raspberry factorial experiment. J. Amer. Soc. Hort. Sci. 130:403-411, doi: 10.21273/JASHS.130.3.403.

Corelli-Grappadelli, L. and D.C. Coston. 1991. Thinning pattern and light environment in peach-tree canopies influence fruit-quality. HortScience 26:1464-1466.

Crisosto, C.H. and G.M. Crisosto. 2005. Relationship between ripe soluble solids concentration (RSSC) and consumer acceptance of high and low acid melting flesh peach and nectarine (Prunus persica (L.) Batsch) cultivars. Postharvest Biol. Technol. 38:239-246, doi: 10.1016/j.postharvbio.2005.07.007.

Crisosto, C.H., R.S. Johnson, T. DeJong, and K.R. Day. 1997. Orchard factors affecting postharvest stone fruit quality. HortScience 32:820 823, doi: 10.21273/HORTSCI.32.5.820.

Crisosto, C.H. and A.A. Kader. 2000. Peach: Postharvest quality maintenance guidelines. 27 Oct. 2020. $<$ http://kare.ucanr.edu/files/ 123826.pdf $>$.

de Souza, V.A.B. 1996. Genetic studies on quantitative traits in peach. PhD Diss., Texas A\&M Univ., College Station.

de Souza, V.A.B., D.H. Byrne, and J.F. Taylor. 1998a. Heritability, genetic and phenotypic correlations, and predicted selection response of quantitative traits in peach: I. An analysis of several reproductive traits. J. Amer. Soc. Hort. Sci. 123:598-603, doi: 10.21273/ JASHS.123.4.598.

de Souza, V.A.B., D.H. Byrne, and J.F. Taylor. 1998b. Heritability, genetic and phenotypic correlations, and predicted selection response of quantitative traits in peach: II. An analysis of several fruit traits. J. Amer. Soc. Hort. Sci. 123:604-611, doi: 10.21273/JASHS.123. 4.604.

Dirlewanger, E., G. Cardinet, K. Boudehri, C. Renaud, S. Monllor, E. Illa, W. Howad, P. Arús, C. Croset, J.L. Poëssel, M. Maucourt, C. Deborde, and A. Moing. 2009. Detection of QTLs controlling major fruit quality components in peach within the European project ISAFRUIT. Acta Hort. 814:533-538, doi: 10.17660/ActaHortic.2009.814.90.

Dirlewanger, E., A. Moing, C. Rothan, L. Svanella, V. Pronier, A. Guye, C. Plomion, and R. Monet. 1999. Mapping QTLs controlling fruit quality in peach (Prunus persica (L.) Batsch). Theor. Appl. Genet. 98:18-31, doi: 10.1007/s001220051035.

Dirlewanger, E., V. Pronier, C. Parvery, C. Rothan, A. Guye, and R. Monet. 1998. Genetic linkage map of peach [Prunus persica (L.) Batsch] using morphological and molecular markers. Theor. Appl. Genet. 97:888-895, doi: 10.1007/s001220050969.

Dirlewanger, E., J. Quero-García, L. Le Dantec, P. Lambert, D. Ruiz, L. Dondini, E. Illa, B. Quilot-Turion, J.M. Audergon, S. Tartarini, P. Letourmy, and P. Arús. 2012. Comparison of the genetic determinism of two key phenological traits, flowering and maturity dates, in three Prunus species: Peach, apricot and sweet cherry. Heredity 109:280-292, doi: 10.1038/hdy.2012.38.

Dumble, S. 2017. GGEBiplots: GGE Biplots with 'ggplot2'. 27 Oct. 2020. <https://cran.r-project.org/web/packages/GGEBiplots/index. html>.

Edge-Garza, D.A., J.J. Luby, and C. Peace. 2015. Decision support for cost-efficient and logistically feasible marker-assisted seedling selection in fruit breeding. Mol. Breed. 35:223, doi: 10.1007/s11032015-0409-z.

Eduardo, I., I. Pacheco, G. Chietera, D. Bassi, C. Pozzi, A. Vecchietti, and L. Rossini. 2011. QTL analysis of fruit quality traits in two peach intraspecific populations and importance of maturity date pleiotropic effect. Tree Genet. Genomes 7:323-335, doi: 10.1007/s11295-0100334-6.

Falconer, D.S. 1989. Introduction to quantitative genetics. Longman, London, UK.

Food and Agriculture Organization of the United Nations. 2020. FAOSTAT. 20 Jan. 2020. <http://www.fao.org/faostat/en/\#data/ QC>.

Fernandez, G.C.J. and J.C. Miller. 1985. Estimation of heritability by parent-offspring regression. Theor. Appl. Genet. 70:650-654, doi: 10.1007/BF00252291.

Fresnedo-Ramírez, J., M.C.A.M. Bink, E. van de Weg, T.R. Famula, C.H. Crisosto, T.J. Frett, K. Gasic, C.P. Peace, and T.M. Gradziel. 2015. QTL mapping of pomological traits in peach and related species breeding germplasm. Mol. Breed. 35:166, doi: 10.1007/ s11032-015-0357-7.

Frett, T.J. 2016. Genetic determinism of Xanthomonas arboricola pv. pruni (Xap) resistance, fruit quality, and phenological traits in peach and incorporation of marker-assisted selection (MAS) in the University of Arkansas peach and nectarine breeding program. PhD Diss., Univ. Arkansas, Fayetteville.

Frett, T.J., K. Gasic, J.R. Clark, D.H. Byrne, T. Gradziel, and C.H. Crisosto. 2012. Standardized phenotyping for fruit quality in peach [Prunus persica (L.) Batsch]. J. Amer. Pomol. Soc. $66: 214-219$.

Frett, T.J., G.L. Reighard, W.R. Okie, and K. Gasic. 2014. Mapping quantitative trait loci associated with blush in peach [Prunus persica (L.) Batsch]. Tree Genet. Genomes 10:367-381, doi: 10.1007/ s11295-013-0692-y.

Hallauer, A.R. and M.J. Carena. 2012. Recurrent selection methods to improve germplasm in maize. Maydica 57:266-283.

Hallauer, A.R., M.J. Carena, and J.B.M. Filho. 2010. Means and variances, p. 33-67. In: A.R. Hallauer, M.J. Carena, and J.B.M. Filho (eds.). Quantitative genetics in maize breeding. Springer, New York, NY. doi: 10.1007/978-1-4419-0766-0_2.

Hansche, P.E. 1983. Response to selection, p. 154-171. In: J. Janick and J.N. Moore (eds.). Methods in fruit breeding. Purdue Univ. Press, West Lafayette, IN.

Hansche, P.E. 1986. Heritability of fruit quality traits in peach and nectarine breeding stocks dwarfed by the dw gene. HortScience 21:1193-1195.

Hansche, P.E. and W. Beres. 1980. Genetic remodeling of fruit and nut trees to facilitate cultivar improvement. HortScience 15:710-715.

Hansche, P.E., C.O. Hesse, and V. Beres. 1972. Estimates of genetic and environmental effects on several traits in peach. J. Amer. Soc. Hort. Sci. 97:76-79. 
Henderson, C.R. 1984. Estimation of variances and covariances under multiple trait models. J. Dairy Sci. 67:1581-1589, doi: 10.3168/ jds.S0022-0302(84)81480-0.

Hernández Mora, J.R., D. Micheletti, M.C.A.M. Bink, E. Van de Weg, C. Cantín, N. Nazzicari, A. Caprera, M.T. Dettori, S. Micali, E. Banchi, J.A. Campoy, E. Dirlewanger, P. Lambert, T. Pascal, M. Troggio, D. Bassi, L. Rossini, I. Verde, B. QuilotTurion, F. Laurens, P. Arús, and M.J. Aranzana. 2017. Integrated QTL detection for key breeding traits in multiple peach progenies. BMC Genomics 18:404, doi: 10.1186/s12864-0173783-6.

Hesse, C.O. 1975. Peaches, p. 285-347. In: J. Janick and J.N. Moore (eds.). Advances in fruit breeding. Purdue Univ. Press, West Lafayette, IN

Holland, J.B., W.E. Nyquist, and C.T. Cervantes-Martínez. 2003. Estimating and interpreting heritability for plant breeding: An update. Plant Breed. Rev. 22:9-112, doi: 10.1002/9780470650202. ch2.

Huber, D.A. 1993. Optimal mating designs and optimal techniques for analysis of quantitative traits in forest genetics. PhD Diss., Univ. Florida, Gainsville.

Kouassi, A.B., C.-E. Durel, F. Costa, S. Tartarini, E. van de Weg, K. Evans, F. Fernandez-Fernandez, C. Govan, A. Boudichevskaja, F. Dunemann, A. Antofie, M. Lateur, M. Stankiewicz-Kosyl, A. Soska, K. Tomala, M. Lewandowski, K. Rutkovski, E. Zurawicz, W. Guerra, and F. Laurens. 2009. Estimation of genetic parameters and prediction of breeding values for apple fruit-quality traits using pedigreed plant material in Europe. Tree Genet. Genomes 5:659672, doi: 10.1007/s11295-009-0217-x.

Lesley, J.W. 1940. A genetic study of saucer fruit shape and other characters in the peach. Proc. Amer. Soc. Hort. Sci. 37:218222.

Lewallen, K.S. and R.P. Marini. 2003. Relationship between flesh firmness and ground color in peach as influenced by light and canopy position. J. Amer. Soc. Hort. Sci. 128:163-170, doi: 10.21273/ JASHS.128.2.0163.

Liang, S., X. Wu, and D. Byrne. 2017. Genetic analysis of flower size and production in diploid rose. J. Amer. Soc. Hort. Sci. 142:306-313, doi: 10.21273 /jashs04173-17.

Lin-Wang, K., K. Bolitho, K. Grafton, A. Kortstee, S. Karunairetnam, T.K. McGhie, R.V. Espley, R.P. Hellens, and A.C. Allan. 2010. An R2R3 MYB transcription factor associated with regulation of the anthocyanin biosynthetic pathway in Rosaceae. BMC Plant Biol. 10:50, doi: 10.1186/1471-2229-10-50.

Lopez, G. and T.M. Dejong. 2007. Spring temperatures have a major effect on early stages of peach fruit growth. J. Hort. Sci. Biotechnol. 82:507-512, doi: 10.1080/14620-316.2007.11512266.

Marini, R.P. and D.L. Sowers. 1994. Peach fruit weight is influenced by crop density and fruiting shoot length but not position on the shoot. J. Amer. Soc. Hort. Sci. 119:180-184, doi: 10.21273/ JASHS.119.2.180.

McCutchan, B.G., J.X. Ou, and G. Namkoong. 1985. A comparison of planned unbalanced designs for estimating heritability in perennial tree crops. Theor. Appl. Genet. 71:536-544, doi: 10.1007/ BF00251202.

Oberle, G.D. and J.O. Nicholson. 1953. Implications suggested by a peach to nectarine sport. Proc. Amer. Soc. Hort. Sci. 62:323-326.

Pirona, R., I. Eduardo, I. Pacheco, C. Da Silva Linge, M. Miculan, I. Verde, S. Tartarini, L. Dondini, G. Pea, D. Bassi, and L. Rossini. 2013. Fine mapping and identification of a candidate gene for a major locus controlling maturity date in peach. BMC Plant Biol. 13:166, doi: 10.1186/1471-2229-13-166.

Quilot-Turion, B. and M. Genard. 2009. Towards the use of modelling in genetic improvement: Example of peach fruit quality. Acta Hort. 817:269-276, doi: 10.17660/ActaHortic. 2009.817.28
Rodriguez, J. and W.B. Sherman. 1986. Relationship between parental flower bud set and seedling precociousness in peach and nectarine, Prunus persica (L.). Batsch. Fruit Var. J. 40:8-12.

Ru, S., D. Main, K. Evans, and C. Peace. 2015. Current applications, challenges, and perspectives of marker-assisted seedling selection in Rosaceae tree fruit breeding. Tree Genet. Genomes 11. doi: 10.1007/ s11295-015-0834-5.

Ruiz, D. and J. Egea. 2008. Phenotypic diversity and relationships of fruit quality traits in apricot (Prunus armeniaca L.) germplasm. Euphytica 163:143-158, doi: 10.1007/s10681-007-9640-y.

Scorza, R., L. May, B. Purnell, and B. Upchurch. 1991. Differences in number and area of mesocarp cells between small-and large-fruited peach cultivars. J. Amer. Soc. Hort. Sci. 116:861-864, doi: 10.21273/ JASHS.116.5.861.

Scorza, R., S.A. Mehlenbacher, and G.W. Lightner. 1985. Inbreeding and co-ancestry of freestone peach cultivars of the eastern United States and implications for peach germplasm improvement. J. Amer. Soc. Hort. Sci. 110:547-552.

Searle, S.R. 1971. A biometrics invited paper. Topics in variance component estimation. Biometrics 27:1-76, doi: 10.2307/ 2528928.

Sherman, W.B., J. Rodriguez, and E.P. Miller. 1984. Progress in lowchill peaches and nectarines from Florida. Proc. Florida State Hort. Soc. 97:320-322.

Tancred, S.J., A.G. Zeppa, M. Cooper, and J.K. Stringer. 1995. Heritability and patterns of inheritance of the ripening date of apples. HortScience 30:325-328, doi: 10.21273/HORTSCI.30.2.325.

Topp, B.L. and W.B. Sherman. 1989. Location influences on fruit traits of low-chill peaches in Australia. Proc. Florida State Hort. Soc. 102:195-199.

Topp, B.L. and W.B. Sherman. 2000. Breeding strategies for developing temperate fruits for the subtropics, with particular reference to Prunus. Acta Hort. 522:235-240, doi: 10.17660/ActaHortic.2000. 522.26.

Topp, B.L., W.B. Sherman, R.E. Stall, G.V. Minsavage, and C.J. Wilcox. 1993. Comparison of greenhouse methods for assessing resistance to bacterial leaf spot in plum. J. Amer. Soc. Hort. Sci. 118:667-671, doi: 10.21273/JASHS.118.5.667.

Veihmeyer, F.J. and A.H. Hendrickson. 1949. The application of some basic concepts of soil moisture to orchard irrigation. Proc. 45th Annu. Mtg. Washington State. Hort. Assoc 45:25-41.

Vileila-Morales, E.A., W.B. Sherman, C.J. Wilcox, and C.P. Andrews. 1981. Inheritance of short fruit development period in peach. J. Amer. Soc. Hort. Sci. 106:399-401.

Visscher, P.M., W.G. Hill, and N.R. Wray. 2008. Heritability in the genomics era - Concepts and misconceptions. Nat. Rev. Genet. 9:255-266, doi: 10.1038/nrg2322.

Vizzotto, M., L. Cisneros-Zevallos, D.H. Byrne, D.W. Ramming, and W.R. Okie. 2007. Large variation found in the phytochemical and antioxidant activity of peach and plum germplasm. J. Amer. Soc. Hort. Sci. 132:334-340, doi: 10.21273/JASHS.132.3.334.

Wang, L. 2009. Heritable pleiotropy of glabrous and saucer shape gene loci from peach and their breeding value. J. Fruit Sci. 26:9298.

Wang, L., Z. Gengrui, F. Weichao, C. Ke, and C. Changwen. 2010. Comparison of heritable pleiotropic effects of the glabrous and flat shape traits of peach. Can. J. Plant Sci. 90:367-370, doi: 10.4141/ CJPS09111.

Weather Underground. 2018. Average high/low temperatures for KCLL. Seasonal averages. 8 July 2018. <http://www.wunderground.com/ NORMS/DisplayNORMS.asp?AirportCode=KCLL\&SafeCityName= College_Station\&StateCode=TX\&Units $=$ none \&IATA $=$ CLL $>$.

Weinberger, J.H. 1948. Influence of temperature following bloom on fruit development period of Elberta peach. Proc. Amer. Soc. Hort. Sci. 51:175-178.

Wen, I.-C., K.E. Koch, and W.B. Sherman. 1995a. Comparing fruit and tree characteristics of two peaches and their nectarine mutants. J. 
Amer. Soc. Hort. Sci. 120:101-106, doi: 10.21273/JASHS. 120.1.101.

Wen, I.-C., W.B. Sherman, and K.E. Koch. 1995b. Heritable pleiotropic effects of the nectarine mutant from peach. J. Amer. Soc. Hort. Sci. 120:721-725, doi: 10.21273/JASHS.120.5.721.

Westfall, P.H. 1987. A comparison of variance component estimates for arbitrary underlying distributions. J. Amer. Stat. Assn. 82:866874, doi: 10.1080/01621459.1987.10478510.

Westwood, M.N. 1993. Temperate-zone pomology. Timber Press, Portland, OR.

Wu, B., S. Li, B. Quilot, M. Génard, and J. Kervella. 2003a. Influence of hairless of fruit epidermis and flesh color on contents of sugars and acids and their relationship in peach. Scientia Agricultura Sinica 36:1540-1544.

Wu, B., B. Quilot, J. Kervella, M. Génard, and S. Li. 2003b. Analysis of genotypic variation of sugar and acid contents in peaches and nectarines through the principle component analysis. Euphytica 132:375-384, doi: 10.1023/A:1025089809421.

Wu, X., S. Liang, and D.H. Byrne. 2019. Heritability of plant architecture in diploid roses (Rosa spp.). J. Amer. Soc. Hort. Sci. 54:236-239, doi: 10.21273/hortsci13511-18.

Yan, W. and N.A. Tinker. 2006. Biplot analysis of multi-environment trial data: Principles and applications. Can. J. Plant Sci. 86:623-645, doi: 10.4141/P05-169. 


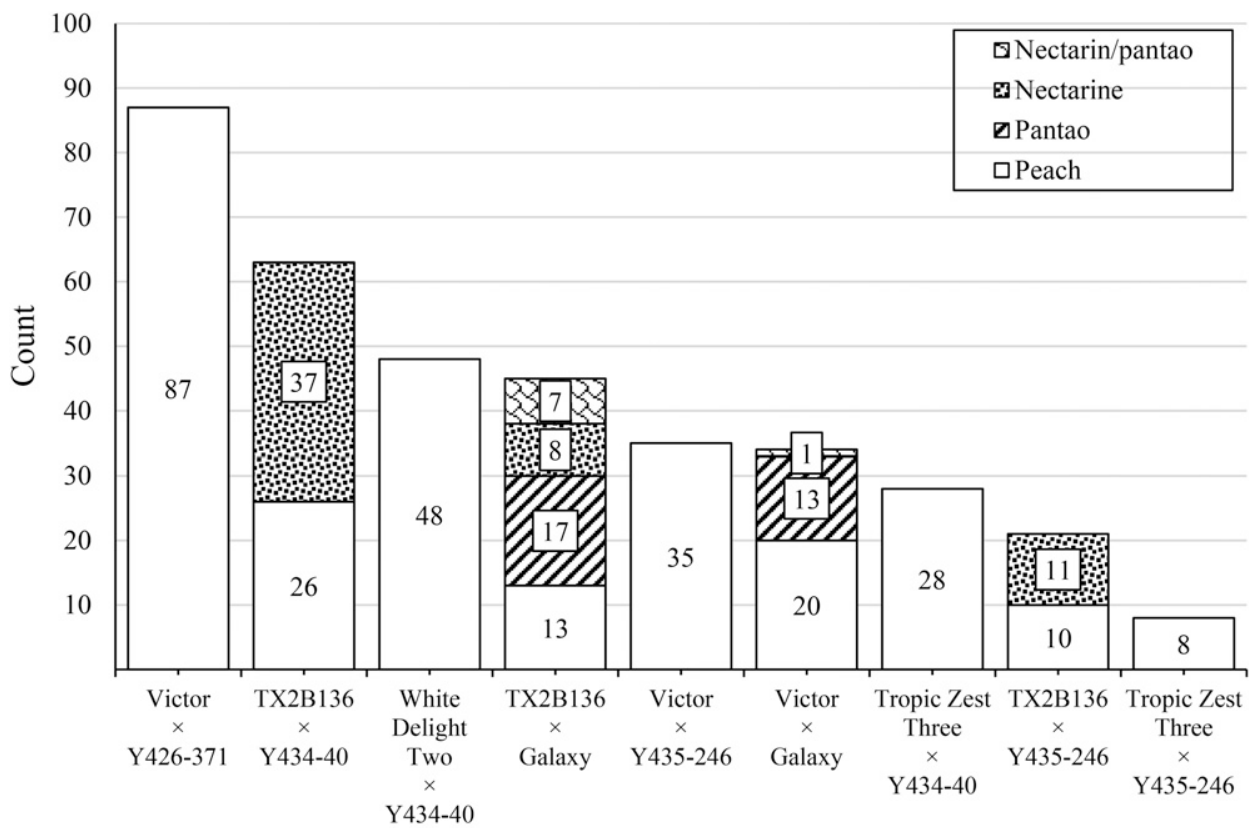

Family

Supplemental Fig. 1. Total number and segregating progenies for pantao (flat shape), nectarine, and peach in nine peach families included in the study.

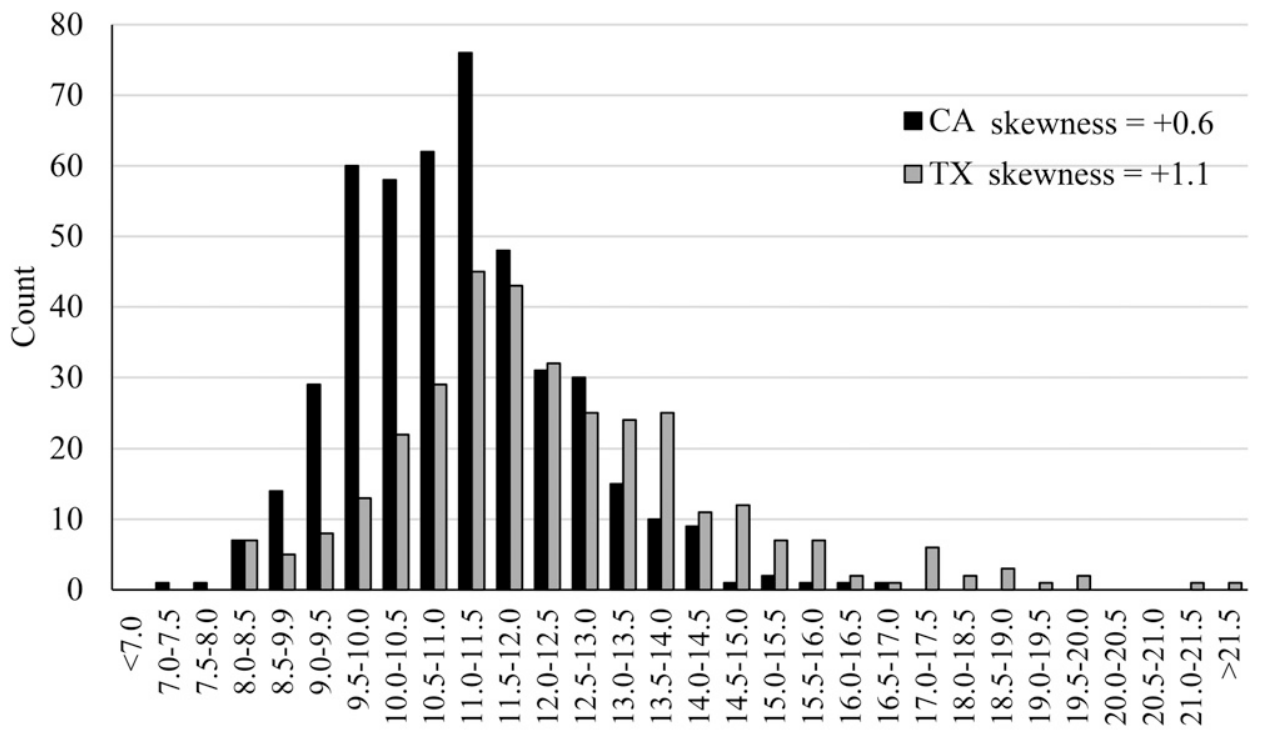

$\operatorname{SSC}(\%)$

Supplemental Fig. 2. Distribution of fruit soluble solids concentration (SSC) of nine peach families evaluated for 2 years at Fowler, CA, and College Station, TX, environments without nectarine and pantao (flat shape) genotypes. 


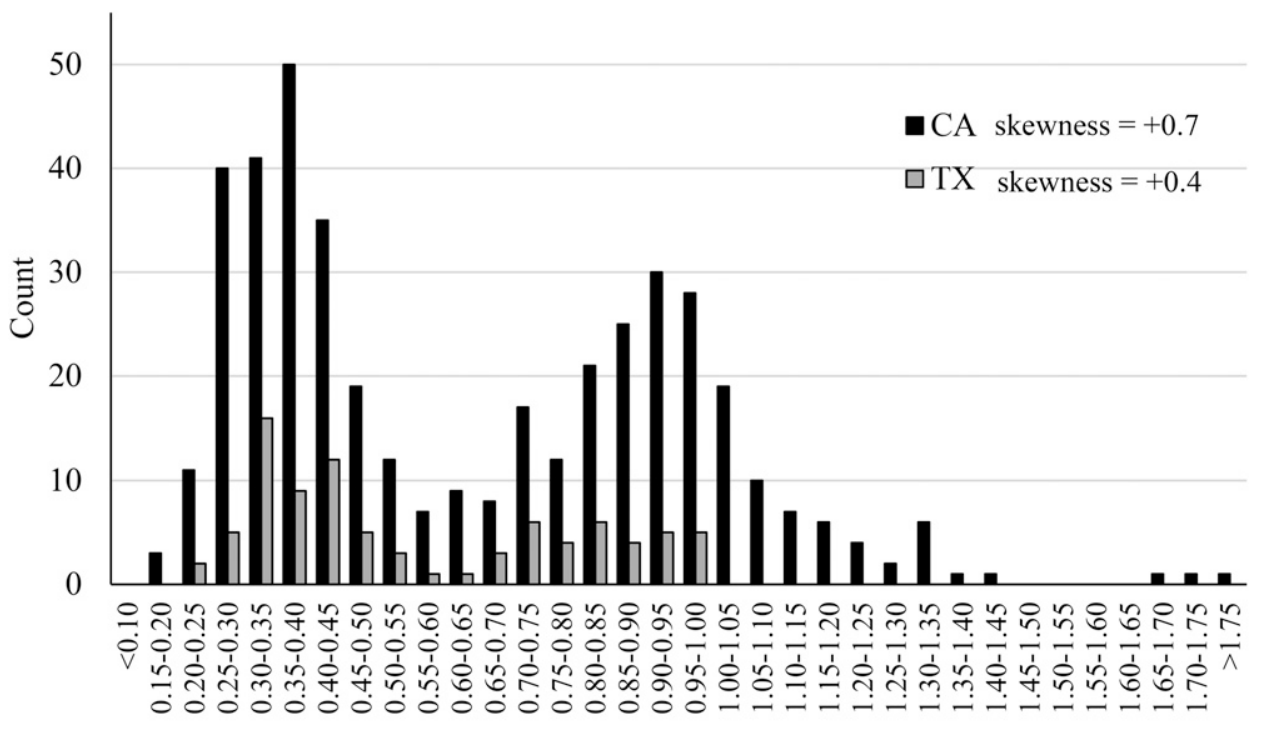

TA (Eq H+/1000 mL juice)

Supplemental Fig. 3. Distribution of titratable acidity (TA) for nine peach families evaluated for 2 years at Fowler, CA, and College Station, TX, environments without nectarine and pantao (flat shape) genotypes.

Supplemental Table 1. Common phenotypic and fruit quality characteristics of the eight peach parents included in the study.

\begin{tabular}{|c|c|c|c|c|c|c|c|c|}
\hline Genotype & $\mathrm{FT}^{\mathrm{z}}$ & $\begin{array}{c}\text { Blooming } \\
\text { date }\end{array}$ & $\begin{array}{c}\text { Ripening } \\
\text { date }\end{array}$ & $\begin{array}{c}\text { Blush } \\
(0-5 \text { scale }) \\
\end{array}$ & $\mathrm{FW}(\mathrm{g})$ & $\mathrm{FD}(\mathrm{mm})$ & SSC (\%) & $\begin{array}{c}\mathrm{TA}\left(\mathrm{Eq} \mathrm{H} \mathrm{H}^{+} / 1000 \mathrm{~mL}\right. \\
\text { of juice })\end{array}$ \\
\hline Y426-371 & $\mathrm{Ne}-\mathrm{Yel}$ & $18 \mathrm{Feb}$. & 28 May & 90 & 79 & 55 & 12.9 & 0.41 \\
\hline Y434-40 & $\mathrm{Ne}-\mathrm{Yel}$ & 6 Feb. & 16 May & $70-90$ & 76 & 55 & 12.7 & 0.44 \\
\hline 'Galaxy'y & Pc-Wh & 19 Feb. & 12 June & $40-70$ & 141 & 77 & 12.6 & 0.24 \\
\hline 'Victor' & Pc-Yel & 11 Feb. & 18 May & $50-70$ & 116 & 64 & 10.7 & 0.87 \\
\hline TX2B136 & Pc-Yel & 5 Feb. & 2 June & $60-80$ & 120 & 63 & 11.0 & 1.29 \\
\hline 'Tropic Zest Three' & Pc-Yel & 5 Feb. & 8 June & $30-40$ & 108 & 62 & 12.2 & 1.00 \\
\hline
\end{tabular}

${ }^{\mathrm{z}} \mathrm{FT}=$ fruit type $(\mathrm{Ne}=$ nectarine, $\mathrm{Pc}=$ peach, $\mathrm{Yel}=$ yellow fleshed, $\mathrm{Wh}=$ white fleshed $)$; Blush $=$ visually based on coverage of red blush on skin using $0-5$ scale $(0=0 \%$ red coverage, $1=1 \%$ to $20 \%, 2=21 \%$ to $50 \%, 3=51 \%$ to $80 \%, 4=81 \%$ to $99 \%, 5=100 \%)$; FW = fruit weight; FD= fruit diameter; $\mathrm{SSC}=$ soluble solids concentration; TA = titratable acidity.

${ }^{\mathrm{y}}$ Pantao (flat shape) is heterozygous for round shape; homozygous pantao types do not survive. 
Supplemental Table 2. Minimum (Min), mean, and maximum (Max) temperatures by month, annual precipitation, and accumulated chill time for 2 years at Fowler, CA, and College Station, TX, environments.

\begin{tabular}{|c|c|c|c|c|c|c|c|c|c|c|c|c|}
\hline \multirow[b]{3}{*}{ Month } & \multicolumn{3}{|c|}{ CA 2011} & \multicolumn{3}{|c|}{ CA 2012} & \multicolumn{3}{|c|}{ TX 2012} & \multicolumn{3}{|c|}{ TX 2013} \\
\hline & \multicolumn{12}{|c|}{ Temp $\left({ }^{\circ} \mathrm{C}\right)$} \\
\hline & Mean & Min & Max & Mean & Min & Max & Mean & Min & Max & Mean & Min & $\overline{M a x}$ \\
\hline Nov. $^{z}$ & 12.4 & 6.4 & 17.8 & 12.2 & 6.7 & 17.2 & 17.1 & 10.3 & 23.4 & 17.3 & 10.0 & 24.1 \\
\hline Jan. & 8.2 & 4.9 & 11.5 & 9.9 & 3.2 & 16.1 & 13.4 & 6.9 & 19.7 & 12.2 & 6.6 & 17.6 \\
\hline Feb. & 9.7 & 3.8 & 15.5 & 11.7 & 5.7 & 17.4 & 14.5 & 9.8 & 19.1 & 14.3 & 8.5 & 20.1 \\
\hline Mar. & 13.1 & 7.6 & 18.4 & 13.5 & 7.2 & 19.7 & 19.6 & 14.5 & 24.4 & 16.0 & 9.1 & 22.7 \\
\hline May & 18.8 & 11.2 & 25.9 & 22.4 & 14.0 & 30.6 & 26.0 & 20.3 & 31.3 & 24.0 & 18.0 & 29.6 \\
\hline June & 24.0 & 16.2 & 31.2 & 25.6 & 17.3 & 33.7 & 29.2 & 23.2 & 34.8 & 29.1 & 22.9 & 35.0 \\
\hline July & 27.9 & 19.6 & 36.0 & 28.6 & 19.9 & 37.1 & 29.6 & 23.9 & 34.7 & 29.7 & 23.4 & 35.4 \\
\hline \multirow[t]{3}{*}{ Aug. } & 28.1 & 19.0 & 36.9 & 30.5 & 21.7 & 38.9 & 30.8 & 24.7 & 36.6 & 30.9 & 24.0 & 37.4 \\
\hline & \multicolumn{12}{|c|}{ Annual precipitation (mm) } \\
\hline & \multicolumn{3}{|c|}{252} & & 244 & & \multicolumn{3}{|c|}{1045} & \multicolumn{3}{|c|}{1000} \\
\hline
\end{tabular}

${ }^{\mathrm{z}}$ Previous year.

${ }^{\mathrm{y}}$ Accumulated chill hours below $7.2^{\circ} \mathrm{C}$ from 1 Nov. to $28 \mathrm{Feb}$.

Supplemental Table 3. Descriptive statistics of 10 peach phenological and fruit quality traits evaluated on nine families for 2 years at Fowler, CA, and College Station, TX, environments without nectarine and pantao (flat shape) genotypes.

\begin{tabular}{|c|c|c|c|c|c|c|c|}
\hline Trait $^{\mathrm{z}}$ & Observations (no.) & Mean & $\sigma_{p}^{2 y}$ & SD & $\mathrm{CV}$ & Min & $\overline{M a x}$ \\
\hline $\mathrm{BD}(\mathrm{d})$ & 789 & 49.0 & 66.1 & 8.1 & 16.6 & 29.0 & 80.0 \\
\hline $\mathrm{RD}(\mathrm{d})$ & 860 & 145.0 & 398.1 & 20.0 & 13.8 & 101.0 & 207.0 \\
\hline FDP (d) & 781 & 95.2 & 499.2 & 22.3 & 23.5 & 50.0 & 159.0 \\
\hline $\mathrm{FD}(\mathrm{mm})$ & 759 & 57.9 & 40.2 & 6.3 & 11.0 & 36.3 & 87.6 \\
\hline Blush (1-5 scale) & 782 & 3.1 & 0.7 & 0.8 & 26.6 & 1.0 & 5.0 \\
\hline Tip (1-9 scale) & 781 & 7.6 & 0.7 & 0.8 & 10.8 & 5.0 & 9.0 \\
\hline $\mathrm{SSC}(\%)$ & 758 & 11.5 & 3.6 & 1.9 & 16.5 & 7.2 & 21.7 \\
\hline $\mathrm{TA}\left(\mathrm{Eq} \mathrm{H}^{+} / 1000 \mathrm{~mL}\right.$ of juice $)$ & 499 & 0.6 & 0.1 & 0.3 & 49.4 & 0.2 & 2.2 \\
\hline
\end{tabular}

${ }^{\mathrm{z}} \mathrm{BD}=$ bloom date in day of the year; $\mathrm{RD}=$ ripe date in day of the year; $\mathrm{FDP}=$ fruit development; $\mathrm{FW}=$ fruit weight; $\mathrm{FD}=$ fruit diameter; $\mathrm{Blush}=$ visually based on coverage of red blush on skin using $0-5$ scale $(0=0 \%$ red coverage, $1=1 \%$ to $20 \%, 2=21 \%$ to $50 \%, 3=51 \%$ to $80 \%, 4=81 \%$ to $99 \%, 5=100 \%)$; Tip = fruit tip visually based on $1-9$ scale $(1=$ very large tip, $3=$ large tip, $5=$ medium protruding tip, $7=$ slight tip, $8=$ flat tip, $9=$ slightly indented tip); Shape $=$ fruit shape visually based on $1-9$ scale $(3=$ large tip and/or suture, $5=$ moderate tip and/or suture, $7=$ mostly round with slight tip and/or suture, $9=$ round fruit); $\mathrm{SSC}=$ soluble solids concentration; TA = titratable acidity.

${ }^{\mathrm{y}} \sigma_{p}^{2}=$ phenotypic variance; $\operatorname{Min}=$ minimum value; Max $=$ maximum value. 
Supplemental Table 4. Descriptive statistics of 10 peach phenological and fruit quality traits evaluated on eight parents for 2 years at Fowler, CA, and College Station, TX, environments.

\begin{tabular}{|c|c|c|c|c|c|c|c|}
\hline Trait $^{z}$ & Observations (no.) & Mean & $\sigma_{p}^{2 y}$ & SD & $\mathrm{CV}$ & Min & $\operatorname{Max}$ \\
\hline$\overline{\mathrm{BD}(\mathrm{d})}$ & 67 & 46.2 & 97.8 & 9.9 & 21.4 & 20.0 & $\overline{70.0}$ \\
\hline $\mathrm{RD}(\mathrm{d})$ & 78 & 150.3 & 242.0 & 15.6 & 10.3 & 124.0 & 179.0 \\
\hline FDP (d) & 67 & 103.5 & 297.6 & 17.3 & 16.7 & 66.0 & 133.0 \\
\hline $\mathrm{FD}(\mathrm{mm})$ & 72 & 61.0 & 85.9 & 9.3 & 15.1 & 47.0 & 88.0 \\
\hline Blush (1-5 scale) & 76 & 3.1 & 0.6 & 0.8 & 25.3 & 1.5 & 5.0 \\
\hline Tip (1-9 scale) & 75 & 8.2 & 0.9 & 0.9 & 11.6 & 6.0 & 9.0 \\
\hline $\operatorname{SSC}(\%)$ & 75 & 12.3 & 3.1 & 1.8 & 14.4 & 8.8 & 17.0 \\
\hline TA $\left(\mathrm{Eq} \mathrm{H} \mathrm{H}^{+} / 1000 \mathrm{~mL}\right.$ of juice $)$ & 36 & 0.5 & 0.1 & 0.3 & 63.5 & 0.2 & 1.3 \\
\hline
\end{tabular}

${ }^{\mathrm{z}} \mathrm{BD}=$ bloom date in day of the year; $\mathrm{RD}=$ ripe date in day of the year; FDP $=$ fruit development; $\mathrm{FW}=$ fruit weight; FD $=$ fruit diameter; $\mathrm{Blush}=$ visually based on coverage of red blush on skin using $0-5$ scale $(0=0 \%$ red coverage, $1=1 \%$ to $20 \%, 2=21 \%$ to $50 \%, 3=51 \%$ to $80 \%, 4=81 \%$ to $99 \%, 5=100 \%)$; Tip = fruit tip visually based on $1-9$ scale $(1=$ very large tip, $3=$ large tip, $5=$ medium protruding tip, $7=$ slight tip, $8=$ flat tip, $9=$ slightly indented tip); Shape $=$ fruit shape visually based on $1-9$ scale $(3=$ large tip and/or suture, $5=$ moderate tip and/or suture, $7=$ mostly round with slight tip and/or suture, $9=$ round fruit); $\mathrm{SSC}=$ soluble solids concentration; TA = titratable acidity.

${ }^{\mathrm{y}} \sigma_{p}^{2}=$ phenotypic variance; $\mathrm{Min}=$ minimum value; $\mathrm{Max}=$ maximum value.

Supplemental Table 5. Trait-wise principal components 1 and 2 variances (PC1 and $\mathrm{PC} 2$ ) of total genotype plus genotype by environment (GGE) variation for bloom date (BD), fruit weight (FW), fruit diameter (FD), blush, tip, shape, and soluble solids concentration (SSC) in peach evaluated at Fowler, CA and College Station, TX environments. Pantao (flat shape) and nectarine genotypes were removed.

\begin{tabular}{lcr}
\hline & \multicolumn{2}{c}{ GGE } \\
\cline { 2 - 3 } Traits $^{z}$ & PC1 (\%) & PC2 (\%) \\
\hline BD & 93.3 & 6.7 \\
FW & 81.8 & 18.2 \\
FD & 81.4 & 18.6 \\
Blush & 82.1 & 17.9 \\
Tip & 81.9 & 18.1 \\
Shape & 73.7 & 26.3 \\
SSC & 88.7 & 11.3 \\
\hline
\end{tabular}

$\overline{\mathrm{z}} \mathrm{BD}=$ bloom date in day of the year; $\mathrm{FW}=$ fruit weight in grams; $\mathrm{FD}=$ fruit diameter in millimeters; Blush = visually based on coverage of red blush on skin using $0-5$ scale $(0=0 \%$ red coverage, $1=1 \%$ to $20 \%, 2=$ $21 \%$ to $50 \%, 3=51 \%$ to $80 \%, 4=81 \%$ to $99 \%, 5=100 \%$ ); Tip = fruit tip visually based on $1-9$ scale $(1=$ very large tip, $3=$ large tip, $5=$ medium protruding tip, $7=$ slight tip, $8=$ flat tip, $9=$ slightly indented tip); Shape $=$ fruit shape visually based on 1-9 scale $(3=$ large tip and $/$ or suture, $5=$ moderate tip and/or suture, $7=$ mostly round with slight tip and/or suture, $9=$ round fruit); $\mathrm{SSC}=$ percent soluble solids concentration. 
Supplemental Table 6. Mean, number of observations, minimum (Min), and maximum (Max) of 10 peach phenological and fruit quality traits evaluated on nine families in Fowler, CA, and College Station, TX, environments. Pantao (flat shape) and nectarine genotypes were removed.

\begin{tabular}{|c|c|c|c|c|c|c|c|c|}
\hline \multirow[b]{2}{*}{ Trait $^{z}$} & \multicolumn{4}{|c|}{ Fowler, CA } & \multicolumn{4}{|c|}{ College Station, TX } \\
\hline & Mean & Observations (no.) & Min & $\overline{\operatorname{Max}}$ & Mean & Observations (no.) & Min & $\overline{\operatorname{Max}}$ \\
\hline$\overline{\mathrm{BD}(\mathrm{d})}$ & 44.9 & 256 & 36.5 & 53.5 & 52.6 & 233 & 29.0 & $\overline{75.0}$ \\
\hline $\mathrm{RD}(\mathrm{d})$ & 151.3 & 256 & 125.0 & 195.5 & 139.2 & 232 & 107.0 & 200.0 \\
\hline FW (g) & 114.7 & 240 & 31.6 & 204.4 & 88.7 & 234 & 45.9 & 156.0 \\
\hline $\mathrm{FD}(\mathrm{mm})$ & 60.4 & 256 & 40.7 & 75.2 & 56.0 & 234 & 45.0 & 67.7 \\
\hline Blush (1-5 scale) & 2.9 & 256 & 1.0 & 5.0 & 3.3 & 231 & 1.0 & 5.0 \\
\hline Shape (1-9 scale) & 7.2 & 254 & 5.5 & 8.5 & 6.9 & 231 & 5.0 & 8.5 \\
\hline SSC (\%) & 11.0 & 255 & 7.6 & 15.2 & 12.3 & 226 & 8.0 & 21.7 \\
\hline $\mathrm{TA}\left(\mathrm{Eq} \mathrm{H} \mathrm{H}^{+} / 1000 \mathrm{~mL}\right.$ of juice $)$ & 0.6 & 252 & 0.2 & 1.6 & 0.6 & 82 & 0.2 & 1.0 \\
\hline
\end{tabular}

${ }^{\mathrm{z}} \mathrm{BD}=$ bloom date in day of the year; $\mathrm{RD}=$ ripe date in day of the year; $\mathrm{FDP}=$ fruit development; $\mathrm{FW}=$ fruit weight; $\mathrm{FD}=$ fruit diameter; $\mathrm{Blush}=$ visually based on coverage of red blush on skin using $0-5$ scale $(0=0 \%$ red coverage, $1=1 \%$ to $20 \%, 2=21 \%$ to $50 \%, 3=51 \%$ to $80 \%, 4=81 \%$ to $99 \%, 5=100 \%)$; Tip = fruit tip visually based on $1-9$ scale $(1=$ very large tip, $3=$ large tip, $5=$ medium protruding tip, $7=$ slight tip, $8=$ flat tip, $9=$ slightly indented tip); Shape $=$ fruit shape visually based on $1-9$ scale $(3=$ large tip and/or suture, $5=$ moderate tip and/or suture, $7=$ mostly round with slight tip and/or suture, $9=$ round fruit); $\mathrm{SSC}=$ soluble solids concentration; TA = titratable acidity.

Supplemental Table 7. Blush, fruit weight, and fruit diameter of nine peach families evaluated at Fowler, CA, and College Station, TX, environments. Pantao (flat shape) and nectarine genotypes were removed.

\begin{tabular}{|c|c|c|c|c|c|c|c|c|c|c|c|c|}
\hline \multirow[b]{3}{*}{ Family } & \multicolumn{3}{|c|}{ Fowler, CA } & \multicolumn{3}{|c|}{ College Station, TX } & \multicolumn{3}{|c|}{ Fowler, CA } & \multicolumn{3}{|c|}{ College Station, TX } \\
\hline & $\begin{array}{c}\text { Blush }^{2} \\
(1-5 \text { scale })\end{array}$ & FW (g) & $\begin{array}{l}\text { FD } \\
(\mathrm{mm})\end{array}$ & $\begin{array}{c}\text { Blush } \\
\text { (1-5 scale) }\end{array}$ & FW (g) & $\begin{array}{l}\text { FD } \\
(\mathrm{mm})\end{array}$ & Blush & FW & FD & Blush & FW & FD \\
\hline & \multicolumn{6}{|c|}{ Mean } & \multicolumn{6}{|c|}{ Observations (no.) } \\
\hline 'Victor' $\times$ Y426-371 & 3.3 & $110.8^{*}$ & $58.8^{*}$ & $3.7^{*}$ & 83.8 & 55.2 & 150 & 122 & 118 & 124 & 150 & 149 \\
\hline TX2B136 × Y434-40 & 2.9 & $109.7 *$ & $59.3^{*}$ & $3.4^{*}$ & 79.8 & 53.3 & 40 & 34 & 35 & 25 & 26 & 26 \\
\hline 'White Delight Two' $\times$ Y434-40 & 2.7 & $116.6^{*}$ & $61.2 *$ & 3.1 & 89.4 & 56.3 & 58 & 44 & 49 & 60 & 74 & 74 \\
\hline TX2B136 × 'Galaxy' & 2.5 & $151.8^{*}$ & $67.0 *$ & 2.9 & 118.6 & 61.7 & 19 & 14 & 15 & 15 & 21 & 20 \\
\hline 'Victor' $\times$ Y435-246 & 2.7 & $120.0 *$ & $60.4^{*}$ & $3.1^{*}$ & 85.5 & 55.1 & 55 & 42 & 44 & 46 & 54 & 53 \\
\hline 'Victor' × 'Galaxy' & 2.8 & $122.5^{*}$ & $60.3^{*}$ & $3.4^{*}$ & 87.3 & 56.2 & 36 & 26 & 26 & 21 & 23 & 23 \\
\hline 'Tropic Zest Three' × Y434-40 & 2.5 & $113.4^{*}$ & $62.3^{*}$ & 2.7 & 88.2 & 56.5 & 48 & 33 & 36 & 39 & 40 & 41 \\
\hline TX2B136 × Y435-246 & 2.9 & 101.8 & 58.9 & 3.4 & 88.2 & 56.6 & 14 & 12 & 11 & 11 & 12 & 12 \\
\hline 'Tropic Zest Three' $\times$ Y435-246 & 2.3 & 118.4 & $62.0 *$ & 2.5 & 96.0 & 54.3 & 13 & 11 & 11 & 6 & 8 & 8 \\
\hline
\end{tabular}

${ }^{\mathrm{z}} \mathrm{Blush}=$ visually based on coverage of red blush on skin using $0-5$ scale $(0=0 \%$ red coverage, $1=1 \%$ to $20 \%, 2=21 \%$ to $50 \%, 3=51 \%$ to $80 \%, 4$ $=81 \%$ to $99 \%, 5=100 \%$ ); FW = fruit weight; $\mathrm{FD}=$ fruit diameter.

*LSMeans of the two environments are significantly different for the same family, with $t$ test $(\alpha=0.05)$.

Supplemental Table 8. Fruit tip, fruit shape, and soluble solid concentration (SSC) of nine peach families evaluated at Fowler, CA, and College Station, TX, environments. Pantao (flat shape) and nectarine genotypes were removed.

\begin{tabular}{|c|c|c|c|c|c|c|c|c|c|c|c|c|}
\hline \multirow[b]{3}{*}{ Family } & \multicolumn{3}{|c|}{ Fowler, CA } & \multicolumn{3}{|c|}{ College Station, TX } & \multicolumn{3}{|c|}{ Fowler, CA } & \multicolumn{3}{|c|}{ College Station, TX } \\
\hline & $\begin{array}{c}\text { Tip }^{z} \\
\text { (1-9 scale) }\end{array}$ & $\begin{array}{c}\text { Shape } \\
\text { (1-9 scale) }\end{array}$ & $\begin{array}{l}\mathrm{SSC} \\
(\%)\end{array}$ & $\begin{array}{c}\text { Tip } \\
\text { (1-9 scale) }\end{array}$ & $\begin{array}{c}\text { Shape } \\
\text { (1-9 scale) }\end{array}$ & $\begin{array}{l}\mathrm{SSC} \\
(\%)\end{array}$ & Tip & Shape & SSC & Tip & Shape & SSC \\
\hline & \multicolumn{6}{|c|}{ Mean } & \multicolumn{6}{|c|}{ Observations (no.) } \\
\hline 'Victor' $\times$ Y426-371 & 7.6 & 7.2 & 10.8 & $7.8^{*}$ & 7.1 & $12.2 *$ & 150 & 150 & 150 & 124 & 125 & 118 \\
\hline TX2B136 × Y434-40 & 7.9 & 7.4 & 11.5 & 7.8 & 7.3 & $12.3^{*}$ & 40 & 41 & 41 & 25 & 25 & 23 \\
\hline 'White Delight Two' $\times$ Y434-40 & 7.2 & $7.0^{*}$ & 11.4 & 7.3 & 6.7 & $13.3 *$ & 57 & 57 & 60 & 60 & 60 & 59 \\
\hline TX2B136 × 'Galaxy’ & 7.4 & 7.4 & 11.4 & $8.0 *$ & 7.1 & 11.6 & 18 & 18 & 19 & 15 & 15 & 13 \\
\hline 'Victor' $\times$ Y435-246 & 7.7 & $7.2^{*}$ & 10.4 & 7.8 & 6.5 & $12.0 *$ & 55 & 55 & 54 & 47 & 47 & 40 \\
\hline 'Victor' $\times$ 'Galaxy' & 7.3 & 7.0 & 10.2 & 7.3 & 6.7 & $11.8 *$ & 36 & 36 & 36 & 21 & 21 & 18 \\
\hline 'Tropic Zest Three' × Y434-40 & 7.9 & 7.4 & 11.5 & 7.7 & 7.1 & 12.0 & 48 & 48 & 48 & 39 & 40 & 33 \\
\hline TX2B136 × Y435-246 & 7.8 & 7.5 & 10.8 & 7.8 & 7.5 & 11.7 & 14 & 14 & 13 & 11 & 11 & 11 \\
\hline 'Tropic Zest Three' $\times$ Y435-246 & 8.0 & 7.5 & 11.4 & 7.7 & 7.7 & 11.7 & 13 & 13 & 13 & 6 & 6 & 6 \\
\hline
\end{tabular}

${ }^{\mathrm{z}}$ Tip $=$ fruit tip visually based on $1-9$ scale $(1=$ very large tip, $3=$ large tip, $5=$ medium protruding tip, $7=$ slight tip, $8=$ flat tip, $9=$ slightly indented tip $)$; Shape $=$ fruit shape visually based on $1-9$ scale $(3=$ large tip and/or suture, $5=$ moderate tip and/or suture, $7=$ mostly round with slight tip and/or suture, $9=$ round fruit).

*LSMeans of the two environments are significantly different for the same family, with $t$ test $(\alpha=0.05)$. 